Department of the Interior

U.S. Geological Survey

Open File Report 93-576

\title{
INVESTIGATION OF THE COAL PROPERTIES AND THE POTENTIAL FOR COAL-BED METHANE IN THE FOREST CITY BASIN
}

\author{
by \\ Joy Bostic \\ Missouri Department of Natural Resources \\ Division of Geology and Land Survey \\ Lawrence Brady \\ Kansas Geological Survey \\ University of Kansas \\ Mary Howes \\ Iowa Department of Natural Resources \\ Geological Survey Bureau
}

\begin{abstract}
Raymond Burchett
Nebraska Geological Survey

Conservation and Survey Division, Institute of Agriculture and Natural Resources, University of Nebraska - Lincoln
\end{abstract}

Brenda S. Pierce

U.S. Geological Survey

Department of the Interior

This report is preliminary and has not been reviewed for conformity with U.S. Geological Survey editorial standards and stratigraphic nomenclature. 


\section{ABSTRACT}

The Forest City basin in Missouri, Kansas, Iowa, and Nebraska, contains substantial coal resources in numerous beds too deep and thin to be mined by conventional methods. However, these coal beds have the potential to produce commercial quantities of coalbed methane. The four State geological surveys of Missouri, Kansas, Iowa, and Nebraska, and the U.S. Geological Survey conducted a preliminary assessment of existing geologic data to determine the thickness and areal extent of deep coals in parts of the Forest City basin. In addition, coal quality, thermal maturity (rank), and coalbed methane composition analyses were performed on some of the coal beds where good-quality coal samples could be obtained.

Methane desorption and composition analyses performed on 11 coal beds from Kansas and Missouri confirm that coalbed methane is indeed present in coal beds of the Forest City basin. Although the volume of that coalbed methane is still unknown, the amount of methane in those areas tested during the current study is sufficient to warrant additional investigations. Reports of excessive methane occurrence in abandoned underground coal mines in Missouri may suggest that greater quantities of coalbed methane may be present at other localities in the basin.

A coalbed methane industry within the Forest City basin would be an energy resource of great economic value to the four States. Cost-benefit analyses for Missouri alone indicate that, in a best-case scenario, an industry the size of that currently operating in the Black Warrior basin of Alabama (an industry that has produced 23.4 billion cubic feet of gas from 910 wells and 590 new jobs) would generate $\$ 74$ million annually in economic benefits to the State of Missouri from business and industry, increased personal income, and local and State government revenue. Even the most conservative scenario would generate over $\$ 4$ million annually to Missouri's economy and $\$ 2.5$ million in benefits to business and industry. The revenue generated in each of the four States would be primarily in underdeveloped rural regions. The results of the current investigation would provide citizens and local governments in these areas with the information necessary to make sensible determinations relative to the benefits of exploring and developing coalbed gas. 


\section{INTRODUCTION}

During the past four years, the State geological surveys of Missouri, Kansas, Iowa, and Nebraska have received numerous inquiries from out-of-state coalbed methane producers requesting geological and analytical data on the deep coal beds in the Forest City basin and the potential for commercial production of coalbed methane. During that period, insufficient geological data and little coal quality or rank data were available on the deep coal beds to accurately assess the potential for coalbed methane in the four-State region of the basin. Most of the coal-related research in the basin had been conducted on near-surface-minable coal reserves close to the perimeter of the basin, and the deeper parts of the basin had not been explored.

These requests from industry stimulated concurrent inquiries from interested parties such as landowners, electric utility companies, local and State officials, and environmental regulatory agencies on potential issues such as new clean energy sources, mineral lease rights, economic benefits to local and State economies, and possible adverse effects on the environment from commercial-scale production of coalbed methane. To respond to these requests and concerns, the four State geological surveys and the U.S. Geological Survey conducted a preliminary assessment of existing geological data to determine the thickness and areal extent of deep coals in parts of the basin. In addition, coal quality, thermal maturity (rank), and coalbed methane composition analyses were performed on some of the coal beds where good-quality coal samples could be obtained.

The Forest City basin is a geologic subsurface structure that underlies northwestern Missouri, northeastern Kansas, southwestern Iowa, and southeastern Nebraska (fig. 1), approximately $46,400 \mathrm{sq} \mathrm{mi}$, and has potential for commercial quantities of coalbed methane. Coalbed methane is a clean-burning fuel often found in economic quantities in coal beds of many ranks (thermal maturities). The methane produced within coal beds is a byproduct of the coalification process in which plant material is converted to coal; much of the coalbed gas generated during this process is retained within the coal matrix. Although minor differences in geologic conditions alter production methods, coalbed methane can be produced, used, and transported in a manner similar to that in which natural gas is produced, used, and transported from conventional gas and petroleum fields. Large quantities of coalbed methane 
are currently being produced from coal beds in the San Juan basin of Colorado and New Mexico and in the Black Warrior basin of Alabama (fig. 1).

The Forest City basin contains a substantial amount of coal resources in numerous beds too deep and thin to be mined by conventional methods. Coalbed methane producers operating in other parts of the United States have overlooked the Forest City basin in their previous exploration efforts because of the lack of geological data on the extent, thickness, quality, and rank of the coal beds in the basin. If coalbed methane is found to be present in commercial quantities in the basin, these deep coal beds would represent a vast, untapped energy source.

This report contains the results of a preliminary assessment of the coal resource and coalbed methane potential in the Forest City basin. Coal beds were evaluated at 10 localities in the basin for thickness, areal distribution, and depth of burial. Samples of a number of the deep coal beds were collected and analyzed for geochemical composition, quality, thermal maturity (rank), gas content, and gas composition. This project is a cooperative effort between the Missouri Department of Natural Resources, Division of Geology and Land Survey; the Kansas Geological Survey; the Iowa Department of Natural Resources, Geological Survey Bureau; the Nebraska Geological Survey; and the U.S. Geological Survey.

\section{GEOLOGIC SETTING OF COAL-BEARING ROCK SEQUENCES}

The Forest City basin is a cratonic basin of Pennsylvanian age underlying adjoining portions of southwestern Iowa, southeastern Nebraska, and northwestern Missouri (figs. 1, 2). The deepest part of the basin is in northeastern Kansas, where the depth of the basement is ??? In this study, the basin's areal limits in each State have been modified from previous work to include important geologic information on the coal-bearing rock sequences at the perimeter of the basin (fig. 2). In Iowa, the edge of the basin is defined as the outcrop/subcrop edge of the Pennsylvanian System strata. In Missouri, the edge of the basin coincides with the 300$\mathrm{ft}$-thickness isopach line of Pennsylvanian strata. The southern boundary of the basin in Kansas and Missouri is the Bourbon Arch. The western edge of the basin in Kansas and Nebraska is the Humboldt fault zone, which forms the eastern boundary of the Nemaha Uplift. 
Coal beds in the Forest City basin are present in two major stratigraphic units, the Atokan and Desmoinesian Series. In ascending order, the coal-bearing units are the Riverton Formation (terminology restricted to Missouri) and the Cherokee, Marmaton, and Pleasanton Groups. In Iowa, the Pleasanton is accorded formation status and is assigned to the Bronson Group. In this study, the top of the coal-bearing geologic rocks is defined as the base of the Hertha Limestone of the Kansas City Group. Coal-bearing sequences consist predominantly of shale and sandstone and subordinate amounts of limestone and coal. The base of the sequence is carbonate rock of Mississippian age. The combined thickness of the coal-bearing units in the basin ranges from the eroded edge of the lower Pennsylvanian rocks on the northern and eastern edges of the basin to a maximum thickness of approximately 900-1,000 $\mathrm{ft}$ in southwestern Iowa. Along the axis of the basin in northeastern Kansas and northwestern Missouri, the combined thickness exceeds 1,000 ft (Anderson and Wells, 1968, p. 274).

\section{GEOLOGIC CHARACTERISTICS OF COAL BEDS IN THE FOREST CITY BASIN}

A large number of coal beds are recognized in the surface and subsurface in all four.States. Over 25 different coal beds have been recognized in Kansas and Iowa, 17 coal beds have been found in Nebraska, and nearly 40 coal beds in Missouri. In all four States, most of the coal. beds are present within the Cherokee Group, and near the perimeter of the basin in Iowa, Kansas, and Missouri several of the coal beds have been mined by conventional methods.

Two of the most important characteristics of the coal beds in the four-State area are their widespread distribution and their persistent thickness which indicate that broad regions in the basin are underlain by coal. In ascending order, coal beds correlated across State boundaries are: the Riverton, Weir-Pittsburg, Mineral, Scammon, Fleming, Tebo, Croweburg (Whitebreast in Iowa), Bevier (Wheeler in Missouri), Summit, Mulky, Mystic (Lexington in Missouri), and Mulberry.

This study evaluated the geologic characteristics of deep coal beds at 10 localities in the basin (figs. 2 - 12). At least 16 individual coal beds were identified from drill core, well cuttings, and geophysical logs. The cumulative thickness of coal beds in individual drill holes ranged 
from $8.3 \mathrm{ft}$ in Clay County, Missouri to $22 \mathrm{ft}$ in Iowa. Individual coal beds have thicknesses of up to $6 \mathrm{ft}$ in Iowa, $5 \mathrm{ft}$ at several localities in Kansas, and as much as $10 \mathrm{ft}$ in one locality in Missouri. On the basis of core holes described in this study, however, most of the coal beds are less than $2 \mathrm{ft}$ thick. At single localities, multiple coal beds having thicknesses of 1 to 2 $\mathrm{ft}$ may provide good targets for development of coalbed methane.

A core test drilled by the Kansas Geological Survey (KGS Edmonds \#1A) (fig. 2) in Leavenworth County penetrated 13 coal beds in the Cherokee Group (figs. 3, 4). Total thickness of the coals is $10.9 \mathrm{ft} ; 5$ of the 13 coal beds exceed $1 \mathrm{ft}$ in thickness (fig. 4). The thickest coal bed is the Riverton (Kansas term), which is $2.1 \mathrm{ft}$ thick (fig. 4). In the Anadarko Petroleum Co. Chapple "A" \#1 well in Doniphan County, Kansas, (fig. 5), 5 coal beds ranging from 1.7 to $4.5 \mathrm{ft}$ in thickness occur within a 150 - $\mathrm{ft}$ thick interval at depths of 1,500 to 1,650 ft. The Alco Rubick \#1 well in Franklin County, Kansas (fig. 6), on the southern side of the basin, penetrated 6 coal beds with cumulative thickness of $10 \mathrm{ft}$; between the depths of 1,120 and $1,220 \mathrm{ft}, 8 \mathrm{ft}$ of coal is present in five different coal beds.

The Iowa Geological Survey core test (IGS CP78) (figs. 2, 7) penetrated 15 coal beds, providing a complete representation of all the identified coal beds in the lower Marmaton and Cherokee Groups in that area. Coal bed thicknesses in that well range from less than 1.0 to $1.9 \mathrm{ft}$; cumulative thickness is $11.7 \mathrm{ft}$. Several of the coal beds are known to be thicker a few miles from the core-hole locality. Detailed studies of the geophysical logs from the Miller \#1 oil test in Montgomery County, Iowa, showed 16 coal beds ranging in thickness from less than 1 to $5 \mathrm{ft}$ and a cumulative thiclness of approximately $22 \mathrm{ft}$ (fig. 7). In the deepest part of the basin in southwestern Iowa, where strata of the Cherokee Group are thickest, insufficient data are available to determine the areal extent of the coal beds; however, the character of the coal beds and associated strata at the edge of the basin suggests a good potential for coal resources in the deeper portion of the basin.

Nine coal beds were identified in the gamma-ray log of the Big "J" Oil Co., No. 5 Sibbernsen well in Richardson County, Nebraska (fig. 8). A preliminary examination of geophysical well logs from 38 other drill holes indicate that coal beds may be present at similar horizons in the Nebraska part of the basin and are most likely continuous across that part of the basin. 
However, no subsurface data are available to determine the thickness of the coal beds or to correlate individual beds with those in adjacent States.

Drill core acquired by the Missouri Department of Natural Resources' Division of Geology and Land Survey in the deeper part of the basin in Atchison County, Missouri (WM-4, figs. 2, 9), contain 16 coal beds having a cumulative thickness of $14.2 \mathrm{ft}$ at depths of 1,050 to $1,800 \mathrm{ft}$. Six of the coals are more than $1 \mathrm{ft}$ thick. The Mineral coal bed, at $2.4 \mathrm{ft}$, is the thickest coal present. Most of these coal beds are also present in the WM-5 core in Nodaway County, Missouri (fig. 10). In WM-5, 15 coal beds have a cumulative thickness of $12.9 \mathrm{ft}$. The thickest coal beds are the Weir-Pittsburg $(2.0 \mathrm{ft})$ and the Mulberry $(1.8 \mathrm{ft})$.

In Missouri, in the south-central part of the basin, seven coal beds were penetrated in the MGS No. 22018 core hole in Clay County (figs. 2, 11). At this location, the Lexington coal bed (Mystic coal of Iowa) is the thickest at $2.9 \mathrm{ft}$. The cumulative thickness of the coal beds is $8.3 \mathrm{ft}$. This core hole did not penetrate the base of the Pennsylvanian strata, which lies at approximately $750 \mathrm{ft}$ below the surface, therefore, no data are available on the lower Cherokee and Riverton coal beds.

In Cass County, Missouri, eight coal beds were penetrated in the Landmark Production; Smith No. 1 well (figs. 2,12 ). The cumulative thickness of the coal beds in this well is 12.1 $\mathrm{ft}$, six of the coals attain individual thicknesses of 1 to $3 \mathrm{ft}$. The Mulberry coal bed is $3 \mathrm{ft}$ thick at this locality.

\section{POTENTIAL FOR COALBED METHANE}

\section{Current Investigations}

The Leavenworth County core hole (KGS Edmonds \#1A) (figs. 2, 4) was drilled through Pennsylvanian rocks into the top of Mississippian carbonates (base of the coal-bearing sequence) to determine the thickness of the coal beds and to determine the amounts of methane that might be present in the coal beds. Thirteen coal beds in the Cherokee Group were penetrated in the core hole. The total thickness of the coal beds was $10.9 \mathrm{ft}$; five coal beds exceeded $1 \mathrm{ft}$ in thickness. The thickest coal is the Riverton coal bed (Kansas 
terminology) which has a total thickness of $2.1 \mathrm{ft}$. The thickness of the coals and the intervals sampled are shown in figure 4. The Leavenworth core hole, however, was not in an optimal locality in the basin for potential maximum methane yield. Limitations of the drill equipment and the convenience of the site dictated the selection of that drill location. Thicker coal beds are known at several other localities [five coal beds ranging from 1.7 to 4.5 $\mathrm{ft}$ thick in a 150-ft interval (1,500 - 1,650 ft) in the Anadarko Petroleum Co., Chapple "A" \#1 well (fig. 5) in Doniphan County, Kansas], and future cores should include thicker coal intervals.

Measurements of gas desorbed from the coal core samples of the Leavenworth County core hole show gas content values of 21 to $94 \mathrm{ft}^{3}$ per ton of coal (table 1). These values were calculated on an ash-free basis following the U.S. Bureau of Mines methodology. However, the methane content would be greater if the values were calculated on a moisture- and ashfree basis. In general, the coals having the higher gas contents are located at greater depths in this core hole (table 1). The Riverton coal bed appears to have the best potential for development at this locality.

After the gas was desorbed, the crushed coal samples and desorbed gas were sent to U.S. Geological Survey laboratories for chemical analyses and gas compositional analyses: Analysis of the gas content of the Riverton coal samples showed a methane content of 96 to 97 percent (table 2). Other coals tested showed methane contents ranging from 72 to 93 percent (table 2). One sample ( 1 Edmonds 4 ) contained large amounts of ethane (11 percent) (table 2). Drill-core samples of two coal beds were obtained from active drilling in southwestern Cass County, Missouri in March 1992 and submitted for gas analysis as well. The composition of gases from these coal beds showed high percentages of methane (table 2).

Two main processes produce coalbed gas: 1) biogenic and 2) thermogenic. Biogenic gas is generated in the early stages of coalification by the degradation of organic matter through a complex series of bacterial processes (Rice and others, in press). The isotope values $\left(\delta^{13} \mathrm{C}\right)$ of biogenic methane are generally in the range of -55 to $-90 \%$ (Rice and others, in press). Although biogenic gas is most often associated with low-rank coals, (lignite to hvCb), it can, in some cases, be generated from hig-rank coals. Thermogenic gas, on the other hand, is 
produced in association with the increased temperatures and pressures. Thermogenic gas begins forming at approximately high volatile $C$ bituminous rank $\left(R_{0} 0.6\right.$ percent) and is isotopically heavier than biogenic methane (Rice and others, in press). Thermogenic gases contain methane but also contain heavier hydrocarbons in the form of ethane, propane, and butane. The isotope $\left(\delta^{19} \mathrm{C}\right)$ values of thermogenic methane are heavier than $-55 \%$ and the isotope values of ethane are heavier than -33\%o (Rice and others, in press). The isotopic compositions of the methane from samples in this study are found in table 2. Unfortunately, isotope values for the heavier hydrocarbons (ethane and pentane) present in these coal beds (table 2) were unobtainable.

In addition to the isotopic analyses (table 2), samples of coal beds from Missouri, Kansas, and Iowa were submitted for a variety of rank-determining analyses. Ultimate and proximate analyses were performed on 10 coal samples from Iowa, 10 coal samples from Kansas, and 5 coal samples from Missouri. The gross calorific value (on a moist, mineral-matter-free basis) was calculated according to American Society for Testing and Materials (1992) standards. In addition, vitrinite reflectance (mean maximum reflectance) analyses were performed on the 5 Missouri and 10 Kansas samples. The results of all these analyses are found in table 3 .

Study of the proximate analyses of the coal samples obtained from coal beds in this study indicate apparent coal ranks ranging from high volatile $\mathrm{C}$ to high volatile $\mathrm{A}$ bituminous (with two exceptions in Iowa). In Kansas, ranks range only from high volatile $B$ bituminous for the stratigraphically higher coal beds to high volatile A bituminous for coal beds below a depth of approximately $950 \mathrm{ft}$. The values determined in the proximate analyses of the core samples from Kansas compare favorably with the proximate values of Bevier coal mined at the Kansas Penitentiary Mine at Lansing, Kansas. This mine was located approximately 5 miles northeast of the KGS Edmonds \#1 core. Coal beds farther to the west in the Kansas and Nebraska portion of the basin might have higher ranks because of greater burial depths and the influence of large-scale geologic structures that might have resulted in higher heat flow and higher coal ranks.

Another determination that measures rank is vitrinite reflectance $\left(R_{0}\right)($ table 3$)$. The vitrinite 
reflectance values also indicate a range in rank from high volatile $\mathrm{C}$ to high volatile $\mathrm{A}$. However, the reflectance values are not as high as calculated calorific values suggest they should be, possibly because of vitrinite reflectance suppression. There are several possible causes of reflectance suppression, but the most likely is the unusually high sulfur content of the coal (table 3), especially if the sulfur is in the form of pyrite.

The rank of the coal determined in this study is in agreement with previous studies conducted on coal beds in Iowa by Hatch and others (1984). These authors reported apparent ranks of high volatile $\mathrm{C}$ bituminous with a mean calorific value of 12,040 BTU/hb (recalculated to moist, mineral-matter-free basis) for 90 coal samples from drill cores and coal mines located in southeastern and south-central Iowa. The depths of the coal beds sampled ranged from a few feet to a maximum of $483 \mathrm{ft}$. Coal beds in the deeper parts of the basin in southwestern Iowa were not analyzed. In Missouri, 113 coal samples from 13 coal beds in 5 districts were collected from active surface mines (Wedge and Hatch, 1980). In general, apparent rank increases in Missouri from high-volatile $\mathrm{C}$ in the north-central part of the State to high-volatile A bituminous in southwestern Missouri. Calorific values (moist, mineral-matter-free basis) ranged from 11,250 BTU/1b in north-central Missouri to 15,250 BTU/lb in the southwestern part of the State. Depth of the coal beds sampled ranged from 40 to $90 \mathrm{ft}$.

In general, coalbed gas content increases with rank (Rice and others, in press). The large increase in the amount of coalbed gas between the ranks of subbituminous $A$ and high volatile $\mathrm{C}$ is due mainly to the fact that thermal processes produce much more methane than the microbial processes operative at the lower ranks (REF). The ability to retain and store methane generated within a coal is also a function of rank (REF). Higher pressure within coal beds increases storage capacity whereas higher temperature decreases storage capacity. At the rank of medium volatile bituminous, for example, some coal beds may have generated more methane than they can store, and the methane may be expelled. Therefore, the rank of the coal beds studied here seems to be at an optimal level for coalbed methane production and storage.

In addition, it should be noted that, although rank is a promising indicator, a stronger 
relationship exists between the quantity and composition of coalbed gas to depth (REF). Therefore, data must be obtained from the deeper parts of the Forest City basin to evaluate the potential for coalbed gas at depth.

Another aspect of coal quality is its relationship to conventional mining. The coal beds analyzed within this study, aside from being very thin and deep, are of poor quality. Coal that is mined conventionally is generally less than 15 percent ash and less than 4 percent sulfur. The ash values for these coal beds range from 6 to more than 35 percent, many being greater than 15 percent. The sulfur content is also quite variable, ranging from 3 to 14 percent. These coal beds, then, would be considered high-sulfur coal. The quality of these coal beds would hinder their use conventionally, mainly because of their ash yield and sulfur contents.

\section{Historical Data}

No direct data are available from historical sources on the quality or quantity of coalbed methane from deep coal beds in the Forest City basin. However, historical reports by the Missouri State mine inspector of excessive methane and methane explosions in shallow underground coal mines may be an indication of coalbed methane in these areas. Several of these mine explosions occurred when the mine shafts were initially constructed; others occurred when the shafts penetrated coal beds lower than the principal beds mined.

Excessive methane and (or) mine explosions were reported in 13 coal mines in 5 counties in Missouri during the period from 1881 to 1905 (fig. 13, table 4). The deepest of these 13 coal beds (tentatively correlated as the Bevier) lies at a depth of $420 \mathrm{ft}$ in southwestern Clay County. Excessive methane was reported in the Mineral coal bed, which was mined near Rich Hill in southwestern Bates County. These mines lie on the southwestern flank of the Schell City-Rich Hill anticline, where the coal beds have been distorted by structural movement (Gentile, 1976). Migration of methane along structural features such as this one may have contributed to the excessive methane reported in the mines.

In Iowa, a few mines were reported to have had problems with carbon dioxide, but only one 
mine was reported to have had problems with methane (Lemish and Palmquist, 1980). Iowa coal mines are relatively shallow, nearly all occurring less than $300 \mathrm{ft}$ below the land surface (Iowa Department of Natural Resources Geographic Information System coal mine database). It is likely that methane generated in the coalification process was lost from these shallow coal beds. As a result, most of the coal mines that operated in Iowa were free of methane gas.

\section{STRUCTURAL GEOLOGY: POTENTIAL IMPACT ON COAL RANK}

Numerous structural features that are present in the Forest City basin may have caused an increase in coal rank on a local and regional scale and may have implications for increased coalbed methane potential. Temperature plays an important role in the thermal maturity of coal. Coal rank, a measure of thermal maturity, increases with increasing temperature. One potential source of heat in the basin is structural movement that displaced coal-bearing geologic units to greater depths in the basin. Coal-quality data within this report are insufficient to determine whether these structural features had an impact on the thermal maturity of the coals. Additional study of coal quality in the vicinity of these structural features may indicate elevated coal rank in some parts of the basin.

Two major tectonic features in the basin are the Nemaha Uplift and the Thurman-Redfield structural zone. The Nemaha uplift involved rock units from Precambrian through Permian age. The main movement was post-Mississippian, but there have been earlier movements (Lee, 1943; Berendsen and Blair, 1986). The Nemaha uplift, with its eastern Humboldt fault zone, forms the western boundary of the Forest City basin in Kansas and Nebraska. Faulting was active before and after deposition of strata in the Cherokee group (Chelikowsky, 1972; Berendsen and Blair, 1986). The Thurman-Redfield structural zone, which underlies the deepest part of the basin in southwestern Iowa, is a horst and graben structure in the Precambrian basement rock. Evidence of movement is present well into the middle Pennsylvanian along the southeastern flank of the structural zone. Structural movement or increased heat flow along these two features may have generated sufficient heat over the geologic past to increase coal rank in parts of the Forest City basin. 
In Missouri, a series of parallel anticlines, synclines, and faults lie in a northwest-southeast direction in the basin (McCracken, 1971). These features, which often displace coal-bearing geologic sequences in the subsurface, may have had the potential to increase coal rank on a local or regional scale. This trend appears to continue into Iowa, although it is less clearly defined because of a thick cover of glacial till and the paucity of useful data.

The Forest City basin, however, is relatively undeformed structurally. This fact is important because, by analogy, most of the coalbed methane in the United States is produced from basins that are relatively undeformed. In large part this is because complex folding and major deformation destroys the cleating system (natural fracture system) within the coal beds, thereby destroying the reservoir properties and reducing the production potential of coalbed methane. A coal-bearing basin must have been subjected to enough structural deformation to develop the cleat system within the coal, but not deformed enough to destroy this vital criterion to coalbed methane development.

\section{DATA AVAILABLE FOR FUTURE INVESTIGATIONS}

The large number of oil and gas tests that have been drilled in the Forest City basin are an important source of information for future investigations on the distribution and amount of coal resources in the basin. The most useful types of data for identifying, correlating, and estimating thickness of the coal beds are the gamma-ray-neutron logs and gamma-ray-density logs.

More than 1,000 gamma-ray-density logs have been logged to a minimum of $900 \mathrm{ft}$ in Kansas. In addition, nearly 4,000 more oil and gas tests have had geophysical logs run to depths less than $900 \mathrm{ft}$ or have had a log type other than the preferred logs mentioned above. There appears to be a good distribution of these deep gamma-ray-density and (or) gammaray-neutron logs in the Forest City basin. Approximately 5,000 wells of all types have been drilled in the basin in Missouri and about 600 wells have been drilled in the Nebraska portion of the basin, including geophysical logs run on 38 deep holes. In the Iowa portion of the Forest City basin, several hundred logs of all types have been run. Analysis of these logs should establish a better correlation of the coal beds in the basin and indicate areas of thicker 
coal beds or combinations of thick coal beds. Such areas could provide potentially high methane volumes from either a single thick coal bed or from multiple-coal bed well completions.

\section{ACKNOWLEDGEMENTS}

We would like to thank Dudley Rice of the U.S. Geological Survey (Denver, CO) for the coalbed gas analyses and for sharing a great deal of information and expertise on coalbed gas. James Pontollillo (U.S.G.S., Reston, VA) performed the vitrinite reflectance analyses. Nancy Gardner (U.S.G.S., Reston, VA) prepared many of the computerized figures used in this report. The Kansas Geological Survey would like to thank William Guy for help on the report. The Missouri Department of Natural Resources', Division of Geology and Land Survey, would like to thank the following people for their generosity in providing coal core samples and access to their drilling operations: Ron Rovenko, Steve Martin, Lomko, Inc.; Bill Blancett, Consulting Geologist; Clifford Pense, Ronald Pense, Pense Brothers Drilling Co. Appreciation is also extended to Wallace $B$. Howe, who provided detailed core descriptions for parts of this report, and shared his considerable knowledge of Pennsylvanian stratigraphy during the course of this investigation.

\section{CONCLUSIONS}

1. Significant coal resources in the Forest City basin have the potential for commercial quantities of coalbed methane, although the volume is not yet known.

2. Methane content ranges from $\mathbf{7 2}$ to $\mathbf{9 7}$ percent by volume for gas in $\mathbf{1 1}$ coal beds sampled during this investigation (table 2). Nine of these coal samples were from the KGS Edmonds \#1A core hole. The other two samples were from the Mulberry coal bed in Cass County, Missouri.

3. The amount of methane present in the nine Kansas coal beds sampled ranged from 21 to $94 \mathrm{ft}^{3}$ per ton of coal (table 1). The Riverton coal bed (Kansas terminology) contained the greatest amount of methane in the KGS Edmonds \#1A core hole, Leavenworth County, Kansas where it was $2.1 \mathrm{ft}$ thick. The Riverton is known to be thicker at other localities in the Kansas part of the basin.

4. In general, coalbed methane content increased with depth at the KGS Edmonds \#1A core hole. 
5. Several individual coal beds are widespread in distribution within the four States in the basin. Individual coal beds, in general, are less than $2 \mathrm{ft}$ thick; however, coals as thick as 6 and $10 \mathrm{ft}$ have been identified within the basin.

6. Multiple coal beds (typically 10 or more), 1 to $2 \mathrm{ft}$ thick, are present in several of the drill cores studied during this investigation. Such localities would be suitable for simultaneous production of coalbed methane throughout the basin.

7. Geochemical analysis and vitrinite reflectance studies of $\mathbf{3 0}$ coal samples analyzed during this investigation show that coal rank ranges from high volatile $\mathrm{C}$ to high volatile A bituminous. The rank of the coal beds, in combination with the compositional gas analyses and isotopic values, is a promising indicator for coalbed methane production and storage and, hence, exploration.

8. Reports of excessive methane in 13 abandoned underground coal mines in the Missouri part of the basin may further indicate the presence of commercial quantities of methane.

9. Although the amount of geological data (geochemical, vitrinite reflectance, and so on) available at this time is insufficient for a thorough assessment of the coalbed methane potential in most parts of the basin, the data collected in the past year indicate that methane is present in the basin and further indicate that there is reason for additional study. Additional core holes need to be drilled in all four States in the basin to acquire this information.

10. Abundant data are available for future investigations in the Forest city basin. Kansas has more than 1,000 gamma-ray-density logs and almost 4,000 oil and gas tests having geophysical logs; Missouri has approximately 5,000 wells of many types; Nebraska has approximately 600 wells and 38 deep geophysical logs; Iowa has several hundred logs of all types. 


\section{REFERENCES CITED}

American Society for Testing and Materials, 1992, Annual Book of ASTM Standards Section 5 - Petroleum Products, Lubricants, and Fossil Fuels. 5.05 - Gaseous Fuels; Coal and Coke.

Anderson, K.H. and Wells, J.S., 1968, Forest City basin of Missouri, Kansas, Nebraska, and Iowa: American Association of Petroleum Geologists Bulletin, v. 52, p. 264-281.

Berendsen, P. and Blair, K.P., 1986, Subsurface structural maps over the Central North American rift system (CNARS), central Kansas, with discussion, Kansas Geological Survey, Subsurface Geology Series 8, 16 p.

Bunker, B.J., Witzke, B.J., Watney, W.L., and Ludvigson, G.A., 1988, Phanerozoic history of the central midcontinent, United States, in Sloss, L.L., ed., Sedimentary Cover - North American Craton, GSA, The Geology of North America, v. D-2.

Chelikowsky, J.R., 1972, Structural geology of the Manhattan, Kansas area, Kansas Geological Survey Bulletin 204, pt. 4, 13 p.

Close, J.C. and Erwin, T.M., 1989, Significance and determination of gas content data as related to coalbed methane reservoir evaluation and production implications: Proceedings of the Coalbed Methane Symposium, 1989, Tuscaloosa, Ala., p. 37-55.

Diamond, W.P. and Levine, J.R., 1981, Direct method determination of the gas content of coal: Procedures and results: U.S. Bureau of Mines Report of Investigations 3515, 36 p.

Gentile, R.J., 1976, The geology of Bates County, Missouri: Missouri Department of Natural Resources, Division of Geology and Land Survey Report of Investigation 59, 89 p.

Hatch, J.R., Avcin, M.J., and VanDorpe, P.E., 1984, Element geochemistry of Cherokee Group coals (Middle Pennsylvanian) from south-central and southeastern Iowa: Iowa Geological Survey Technical Paper 5, 108 p.

Lee, W., 1943, The stratigraphy and structural development of the Forest City basin in Kansas, Kansas Geological Survey Bulletin 51, 142 p.

Lemish, J. and Palmquist, R.C., 1980, The geology of the deep coal in Iowa: Final report to U.S. Department of Energy under contract DEAC21-77ET12523, $104 \mathrm{p}$.

McCracken, M.H., 1971, Structural features of Missouri: Missouri Geological Survey and Water Resources Report of Investigations 49, 99 p.

McCulloch, C.M., Levine, J.R., Kissell, F.N., and Deal, M., 1975, Measuring the 
methane content of bituminous coalbeds: U. S. Bureau of Mines Report of Investigations 8043,22 p.

Rice, D., Law, B., and Clayton, J., in press, Coalbed gas - an undeveloped resource, in Howell, D.G., The future of energy gases, U.S.G.S. Professional paper 1570.

Wedge, W. and Hatch, J.R., 1980, Chemical composition of Missouri coals: Missouri Department of Natural Resources, Division of Geology and Land Survey Report of Investigation $63,102 \mathrm{p}$. 


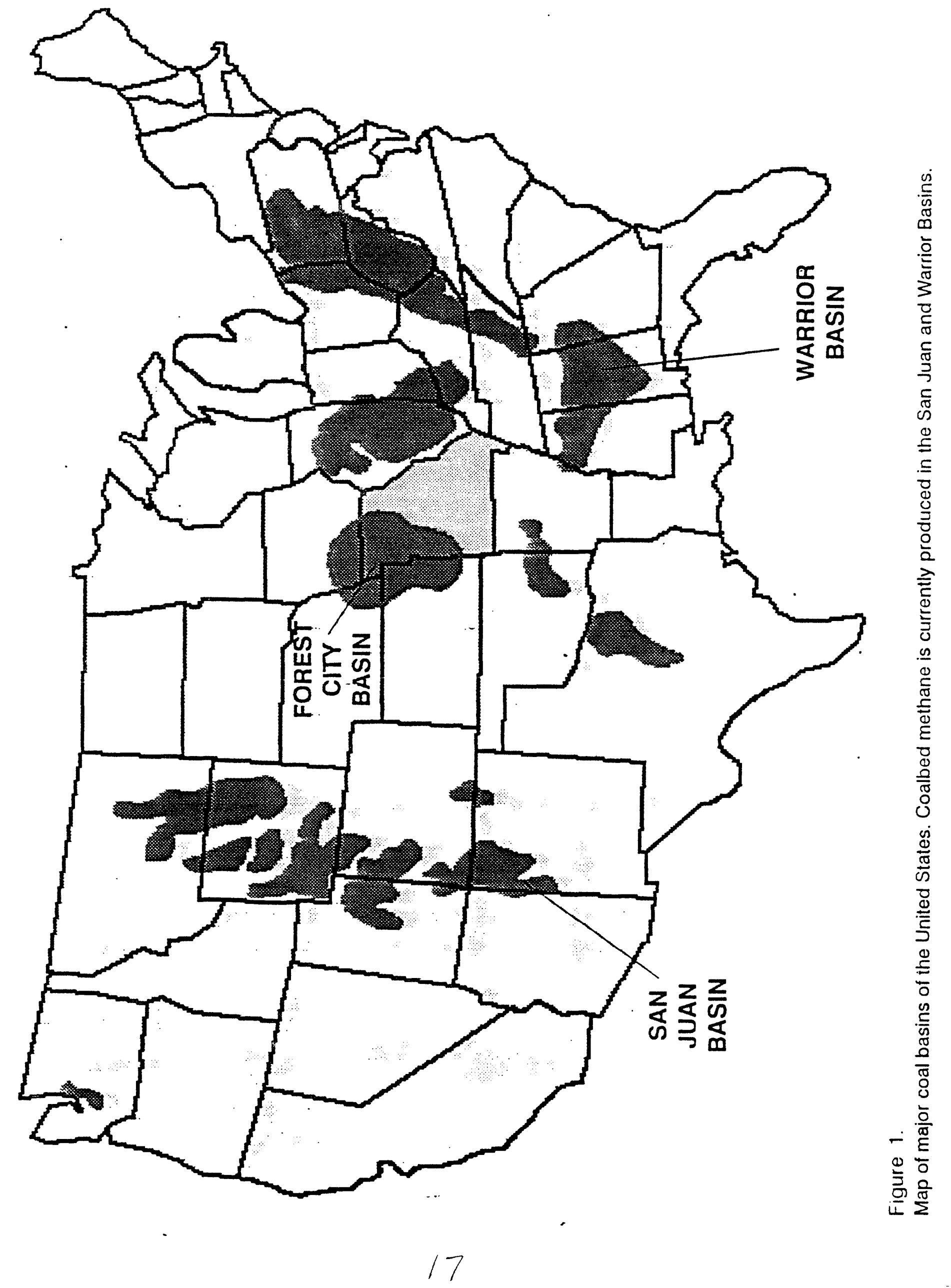



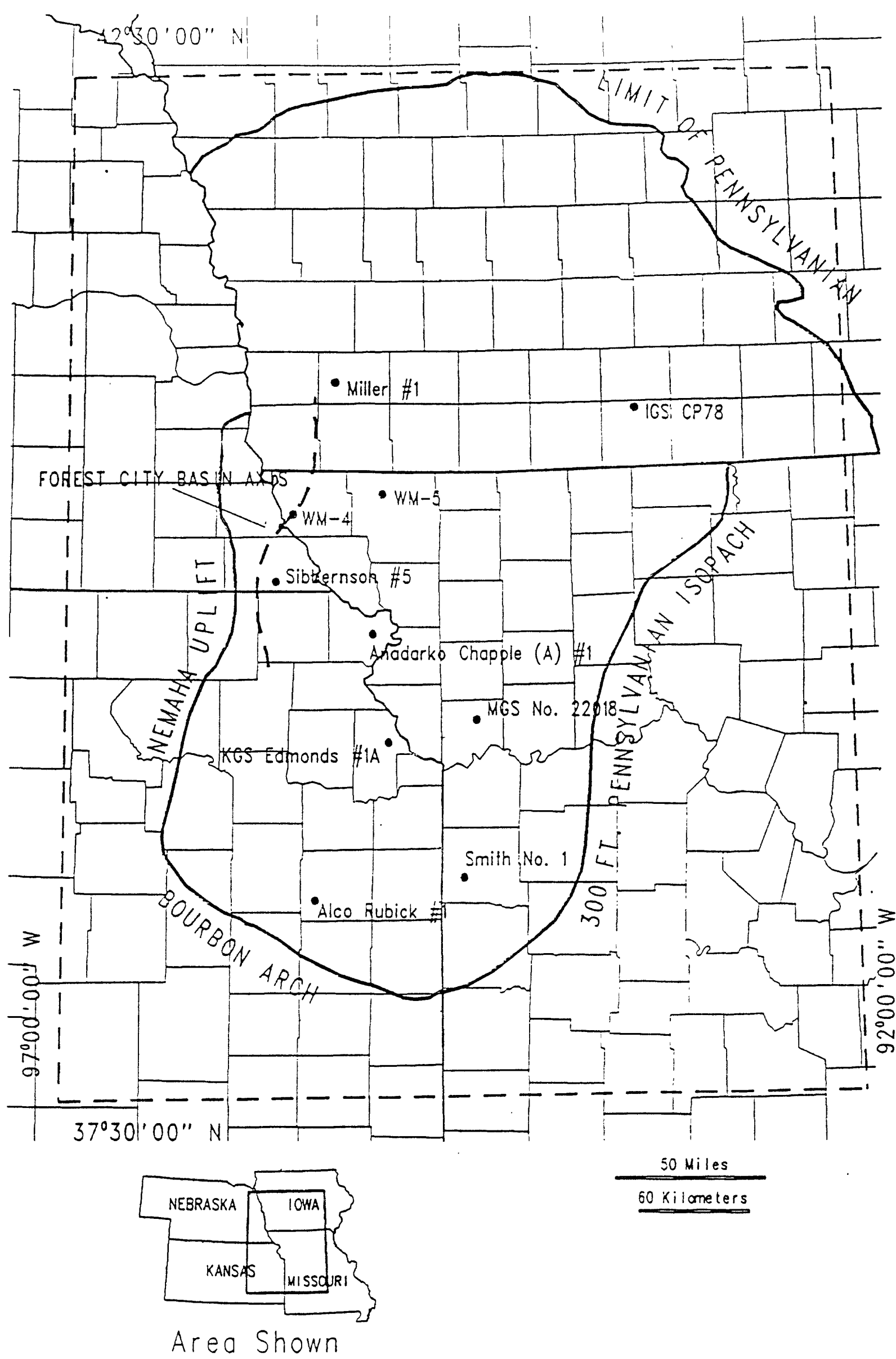

Figure 2. Forest City basin study area showing location of drill holes discussed in this study. 


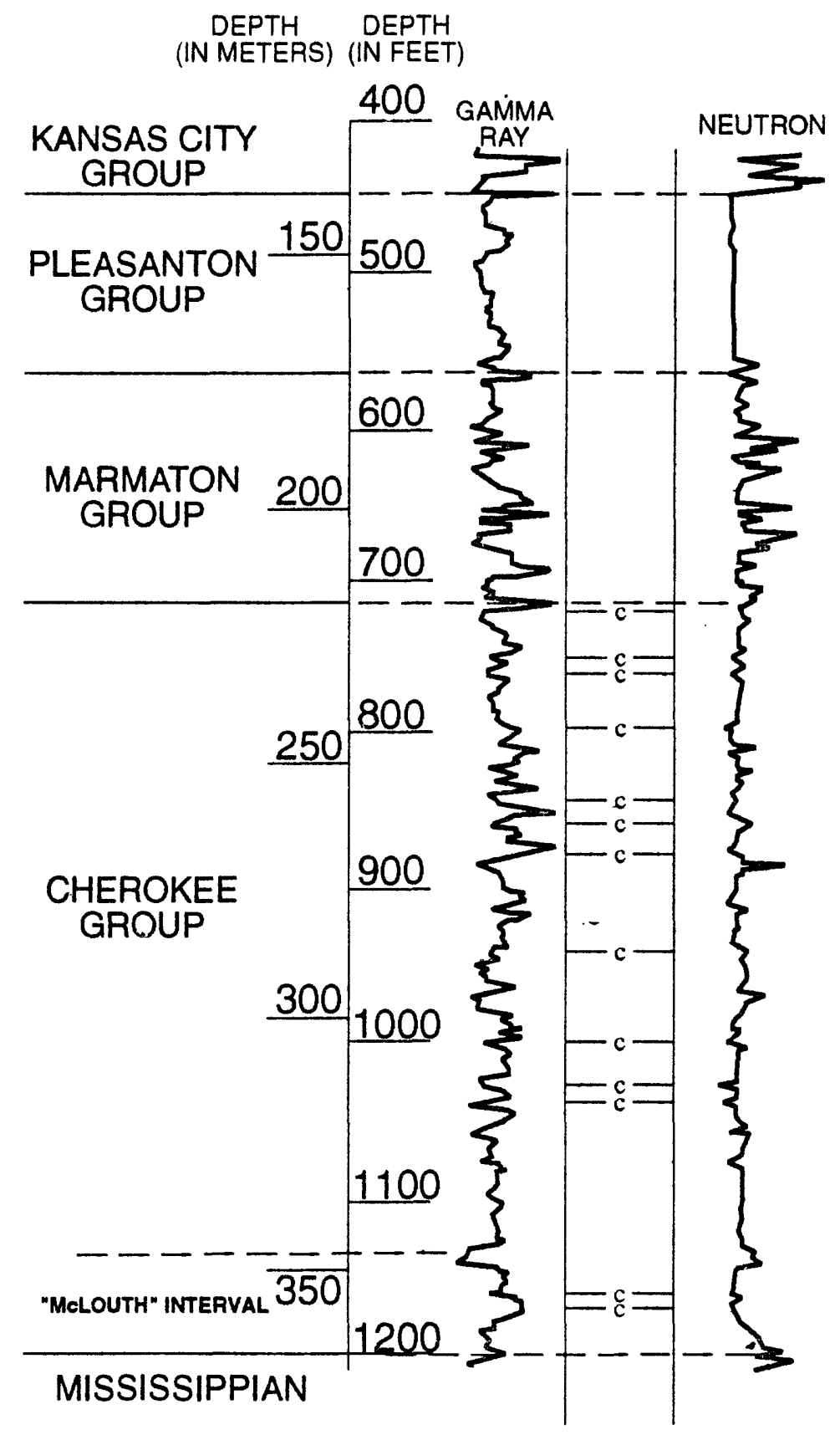

Figure 3. Geophysical log, Kansas Geological Survey Edmonds \#1A, NW, SW, sec. 35, T. 9 S., R. 22 E., Leavenworth County, Kansas.

Location shown in figure 2. 


$$
\begin{array}{ll}
\text { ZEPTH } & \text { OOLBED NAME } \\
\text { NNFETI } & \text { AND THICKNESS }
\end{array}
$$

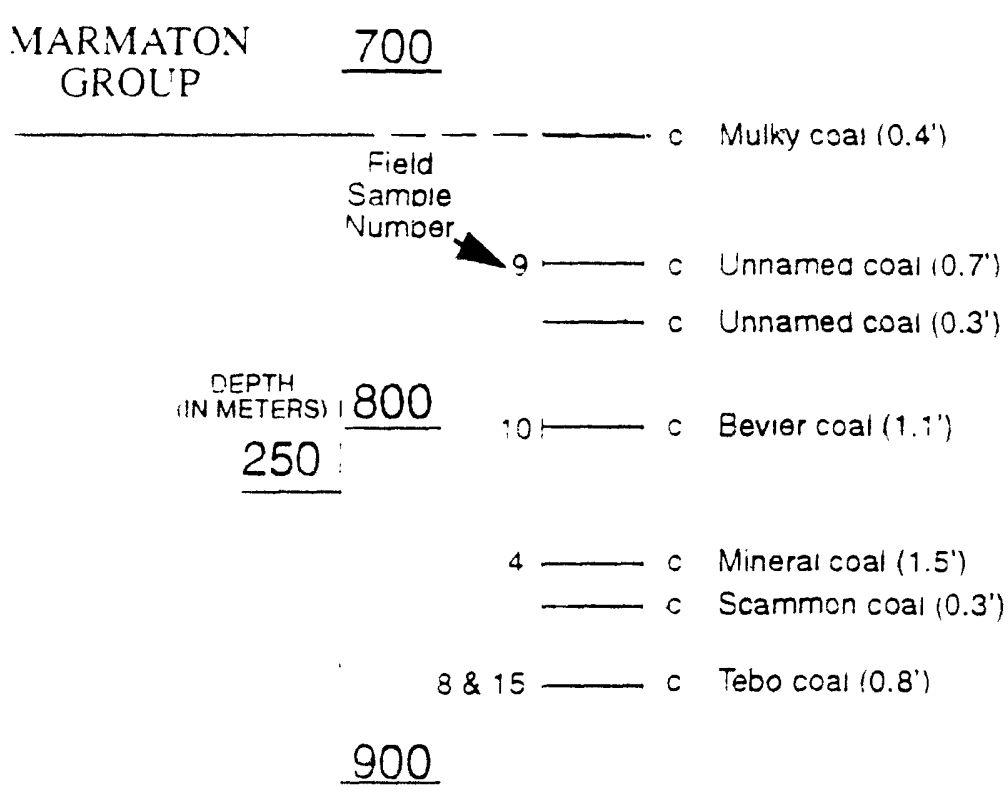

\section{CHEROKEE \\ GROLP}

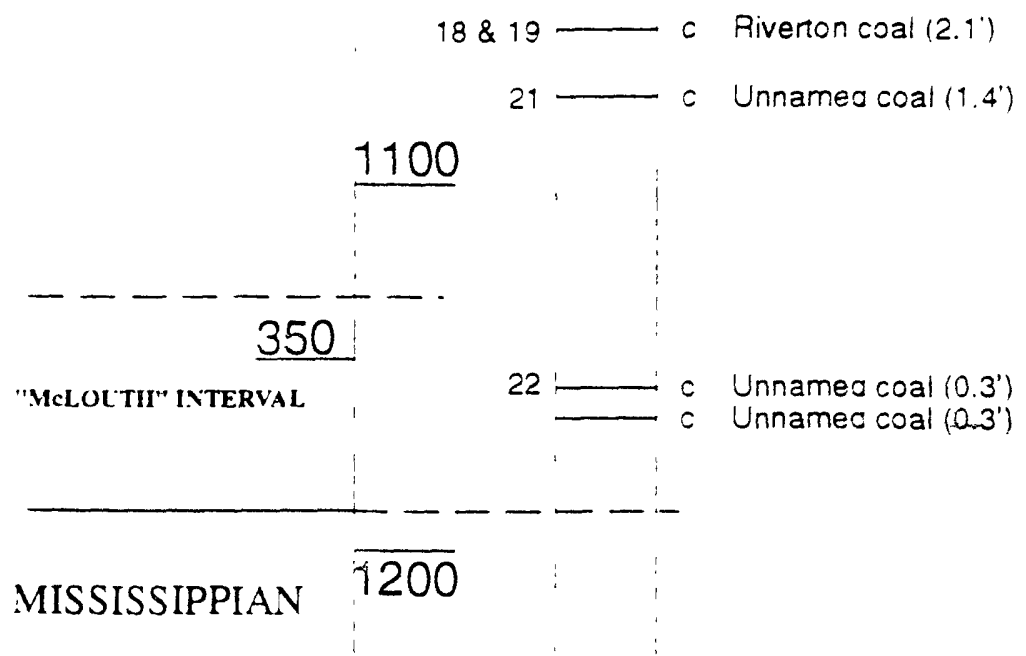

Figure 4. Geologic column, Kansas Geological Survey Edmonds \#1A, NW, SW, sec. 35, T. 9 S., R. 22 E., Leavenworth County, Kansas. Location shown in figure 2. 


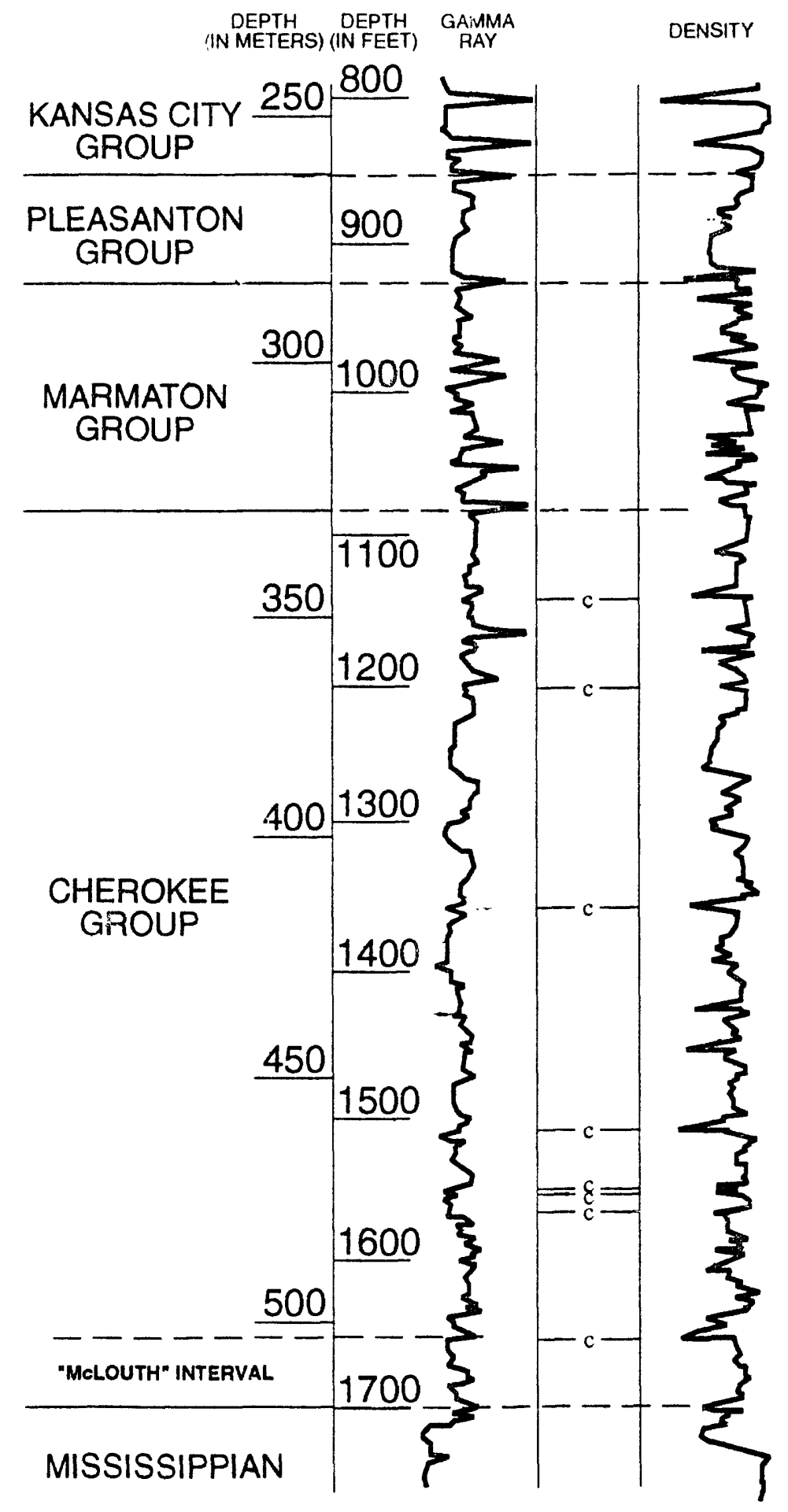

Figure 5. Geophysical log, Anadarko Chapple "A" \#1, NW, sec. 13, T. 20 E., R. 3 S., Doniphan County, Kansas. Location of well shown in figure 2. 


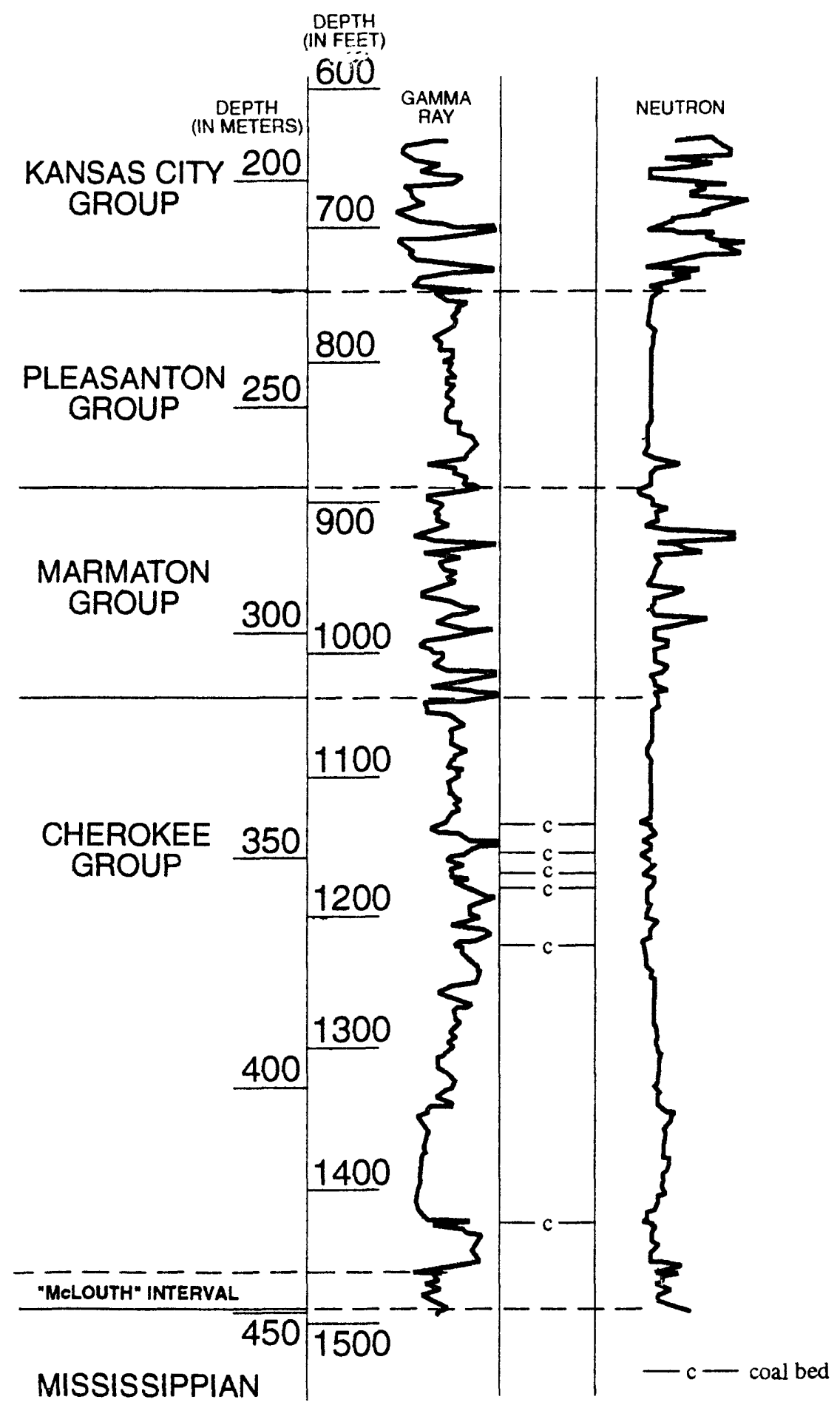

Figure 6. Geophysical log, Alco Rubick \#1, SW, SE, sec. 16, T. 18 S., R. 18 E., Franklin County, Kansas. Location shown in figure 2. 


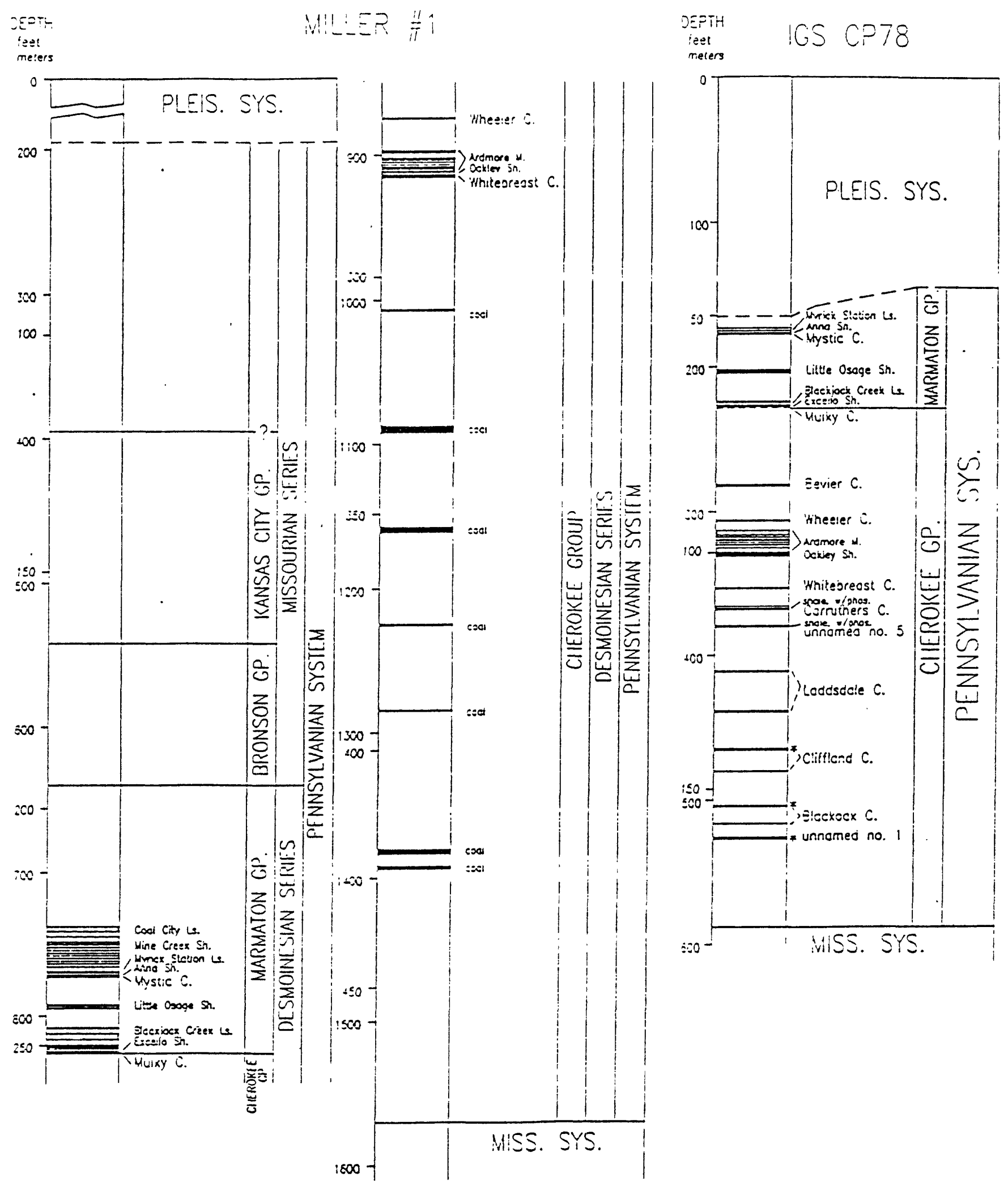

Figure 7. Two sections through Pennsylvanian rocks in Iowa illustrating coal beds in the Cherokee and Marmaton groups together with related strata which are significant stratigraphic markers. Note the thicker Cherokee section in Miller \#1 compared with CP78. The coals below the Whitebreast in Miller \# 1 could not be correlated at this time. The section for Miller \#1 was prepared from geophysical logs. The section for CP78 was prepared from the core description. The asterisks $\left(^{*}\right)$ indicate coals which were sampled for ultimate, proximate, and calorific value analysis. 
Figure 9. Geologic column showing depth and thickness of coal beds in Well No. WM-4, Atchison County, Missouri. NW, NE, sec. 17, T. 64 N., R. 41 W. Location of well shown in figure 2. Asterisks denote coal beds sampled for geochemical and vitrinite reflectance analyses.

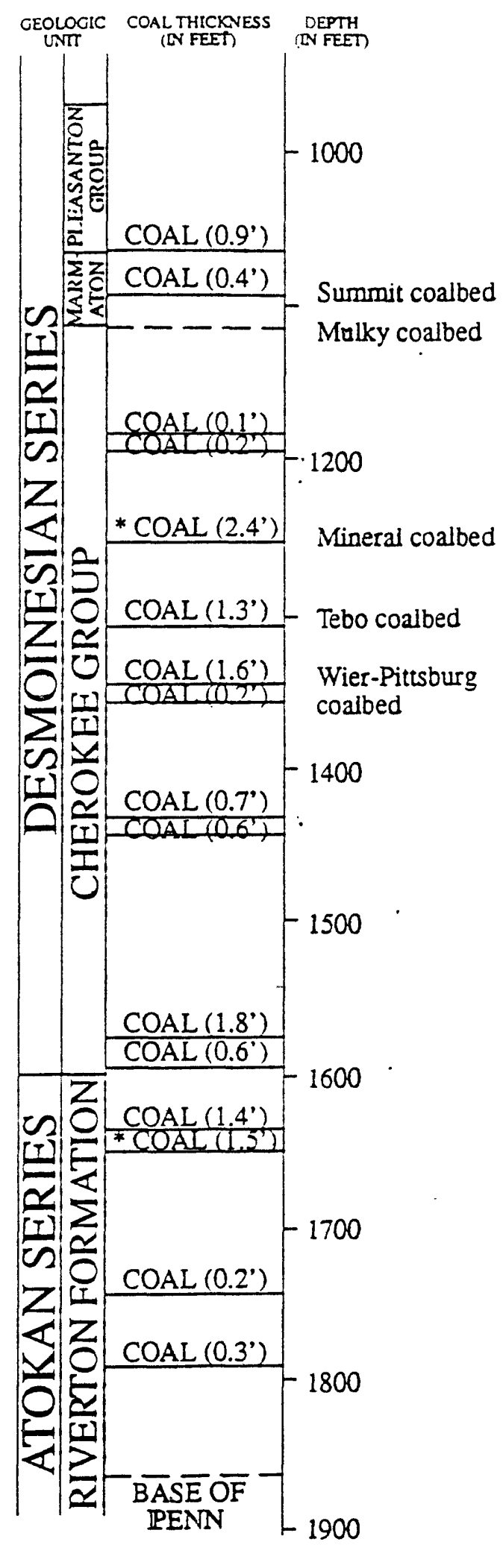


Figure 10. Geologic column showing depth and thickness of coal beds in Well No. WM-5, Nodaway County, Missouri. NW, SE, sec. 10, T. 65 N., R. $36 \mathrm{~W}$. Location of well shown in figure 2. Asterisk denotes coal beds sampled for geochemical and vitrinite reflectance analyses.

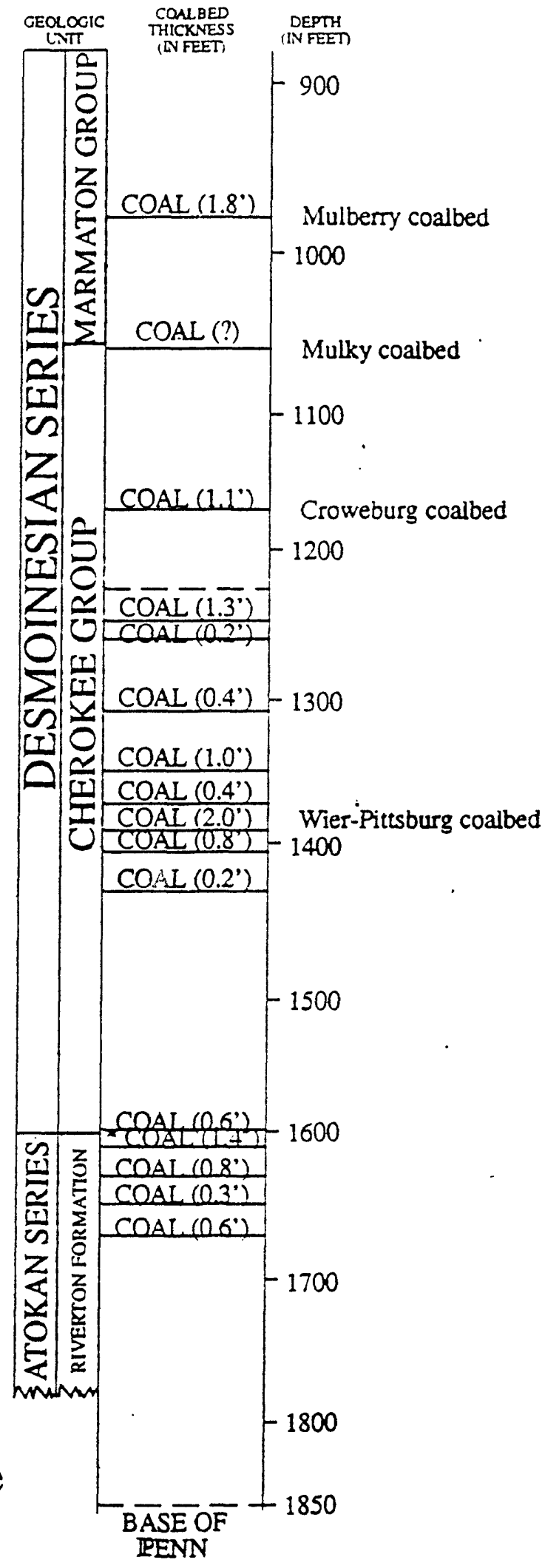




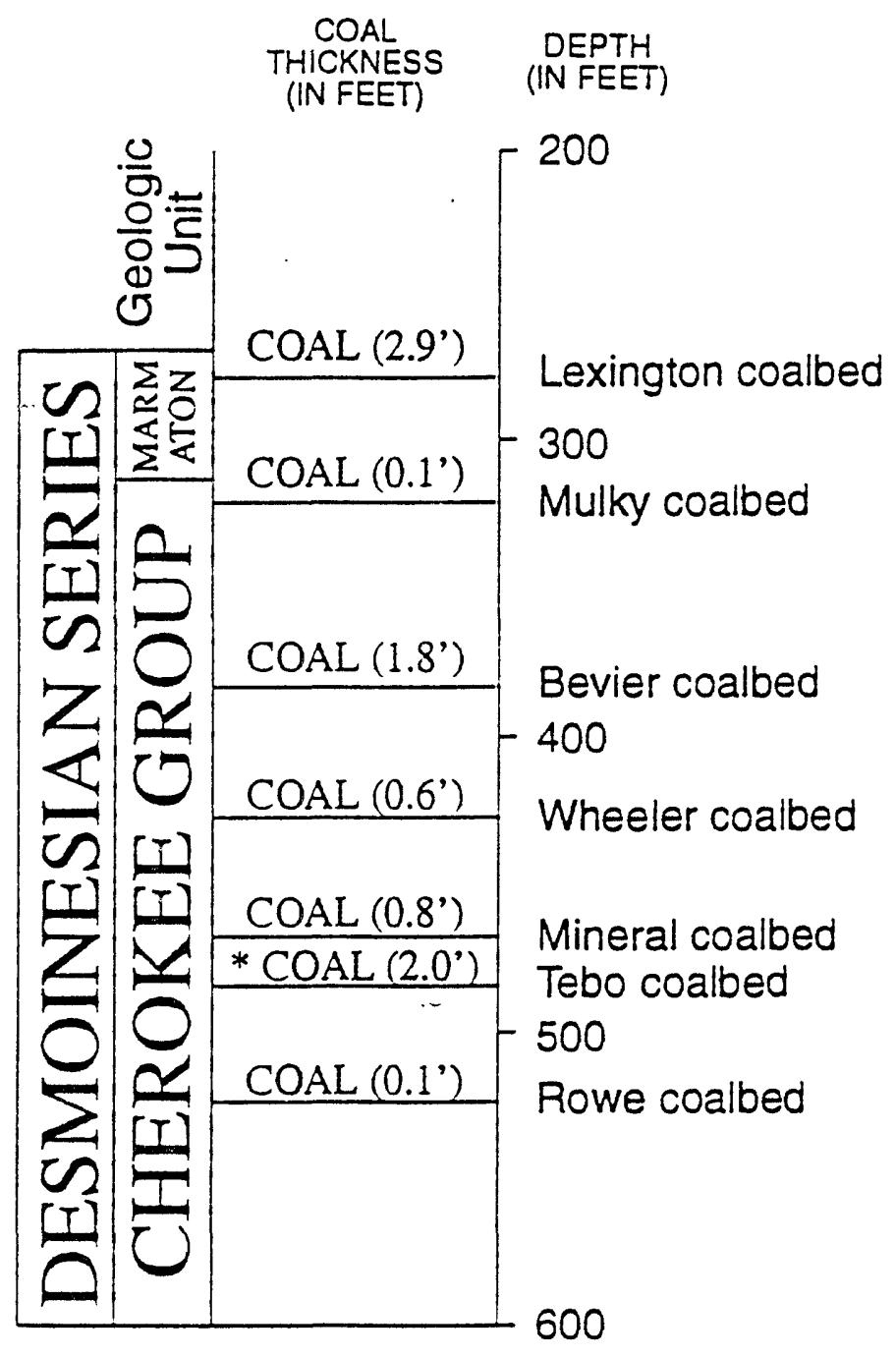

Figure 11. Geologic column showing depth and thickness of coal beds in Well No. 22018, Clay County, Missouri. NW, SE, sec. 22, T. 53 N., R. 31 W. Location of well shown in figure 2. Asterisk denotes coal bed sampled for geochemical and vitrinite reflectance analyses. 


\section{- MISSOURI DEPARTMENT OF NATURAL RESOURCES DIVISION OF GEOLOGY AND LAND SURVEY}

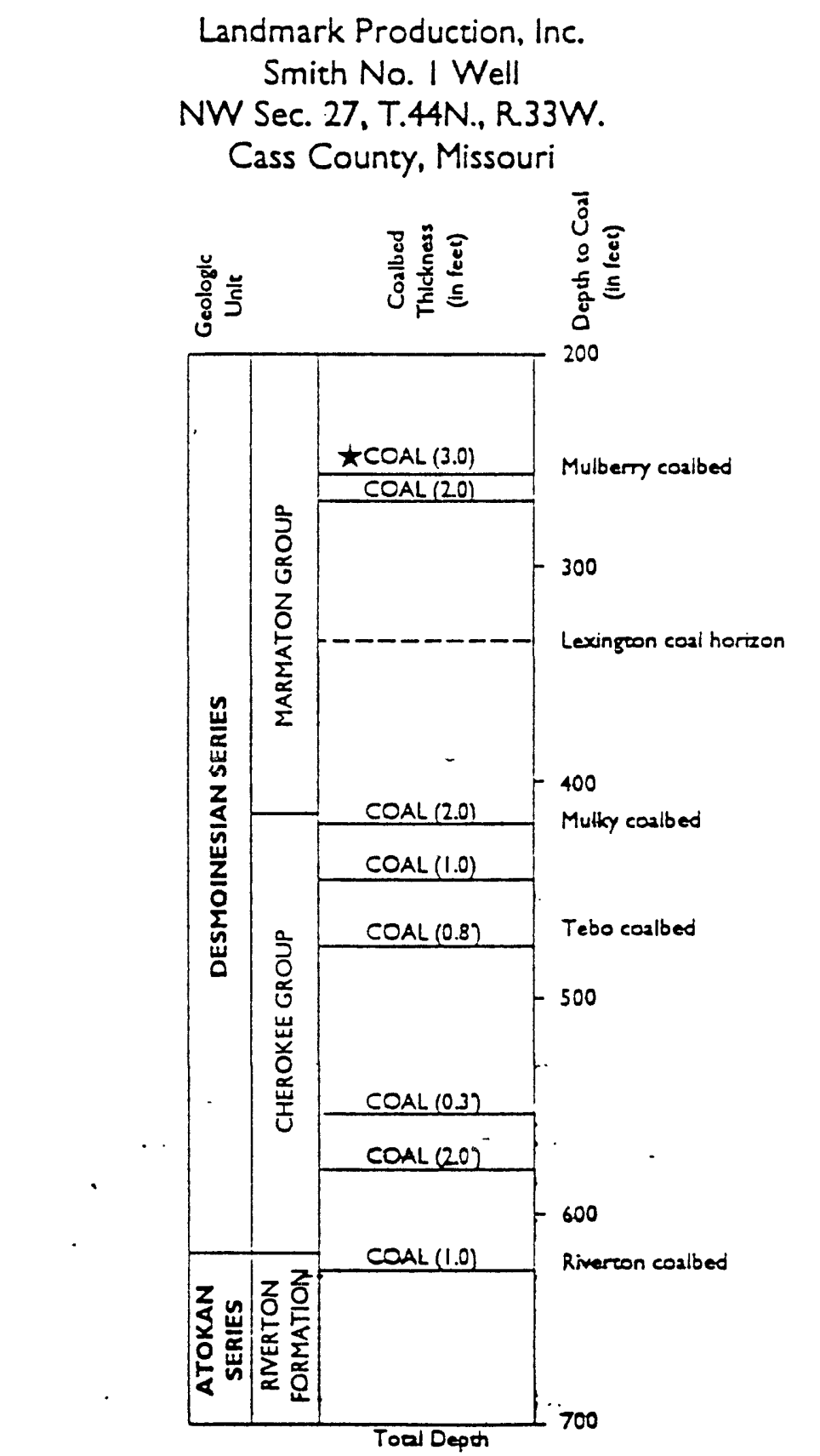

tDenotes coaibed samplod for geochemial and vitrinice reflecence analyses.

Methane desorption and methane qualtiy tese were also conducred on this coalbed.

Figure 12 Geologic column showing depth and thickness of coalbeds in the Smith No. 1 Well. 


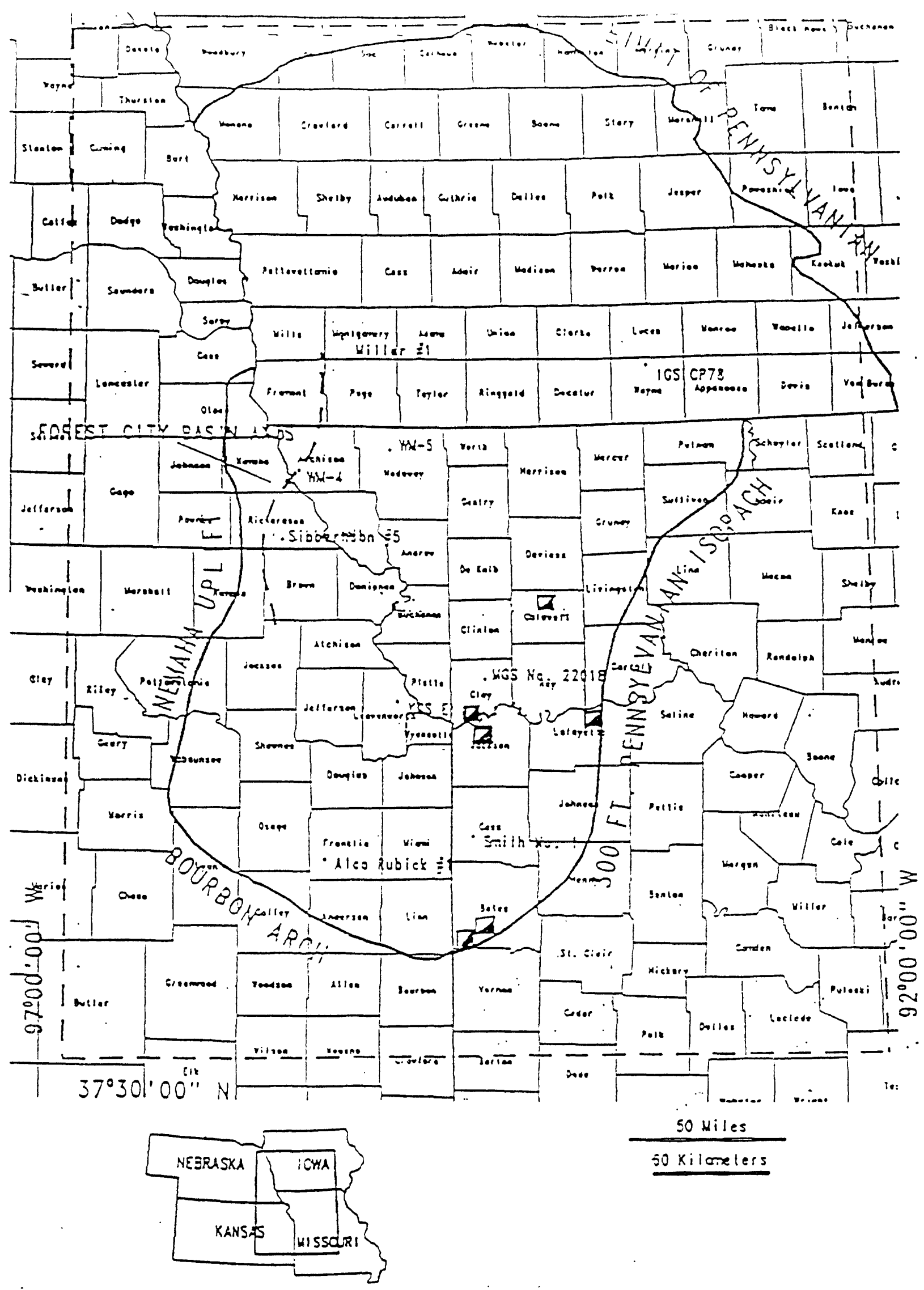

Figure 13. Location map of abandoned underground coal mines, indicated by rectangles, in the Missouri part of the Forest City basin in which excessive methane or explosions were reported by the state mine inspector. 


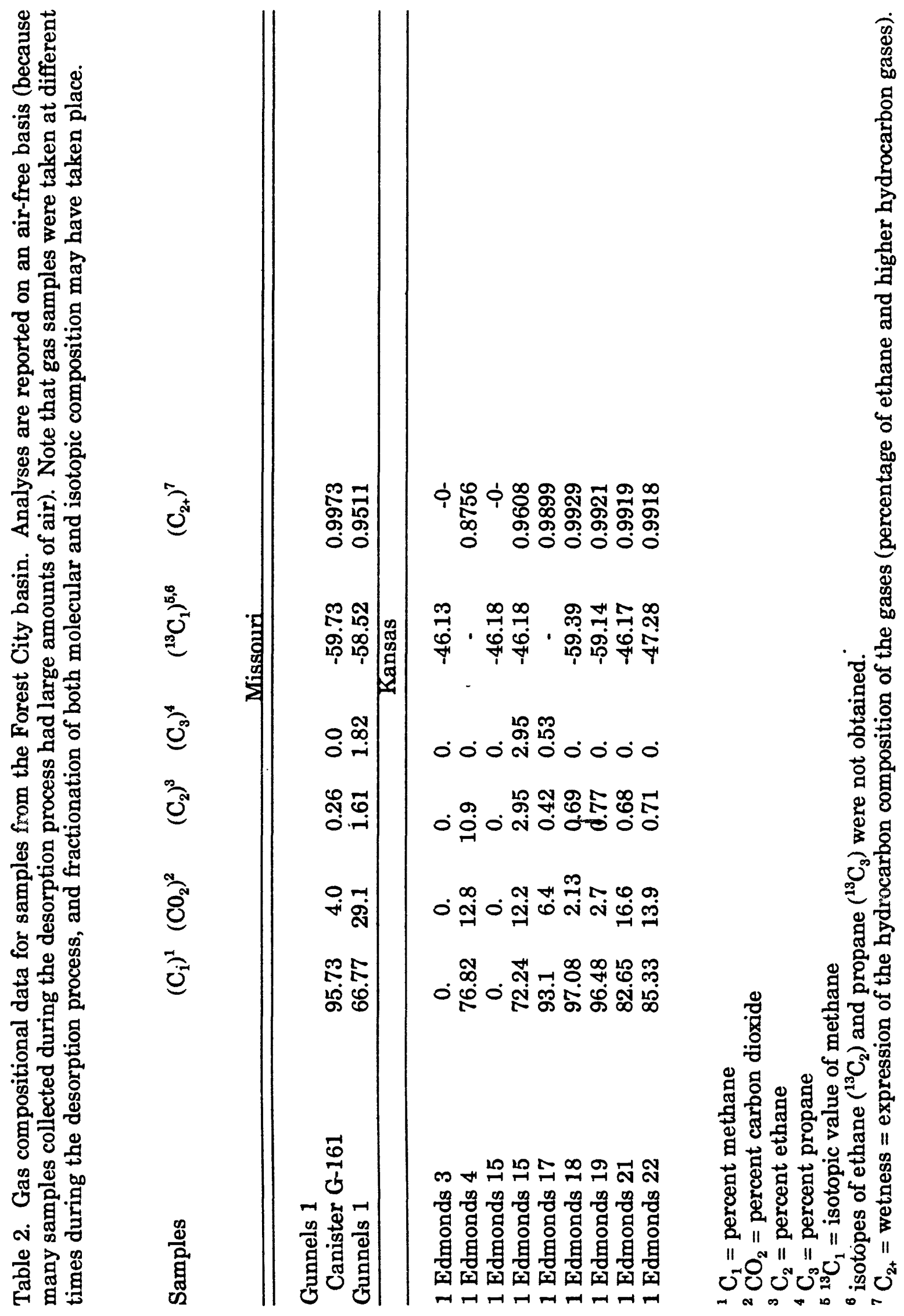




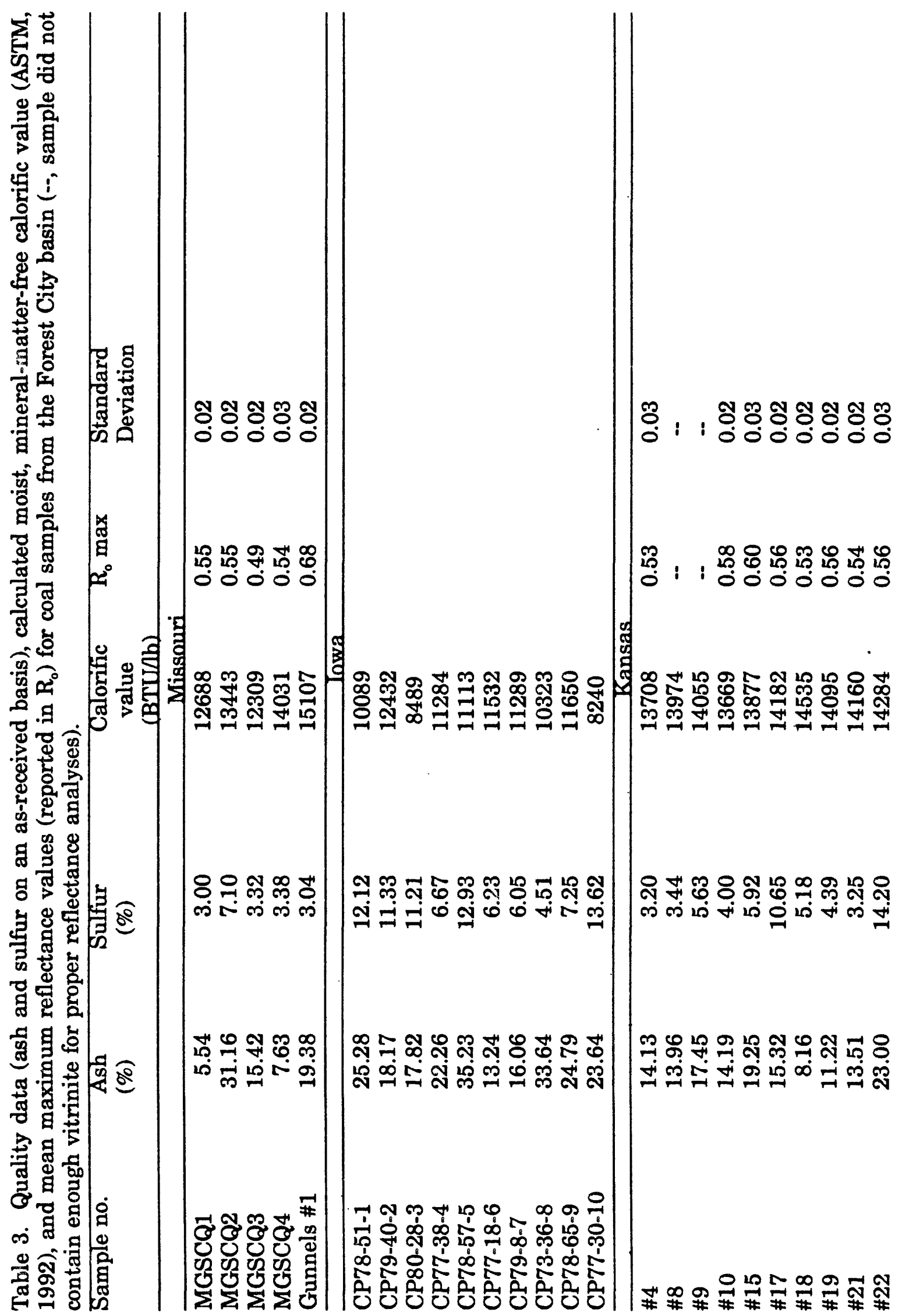




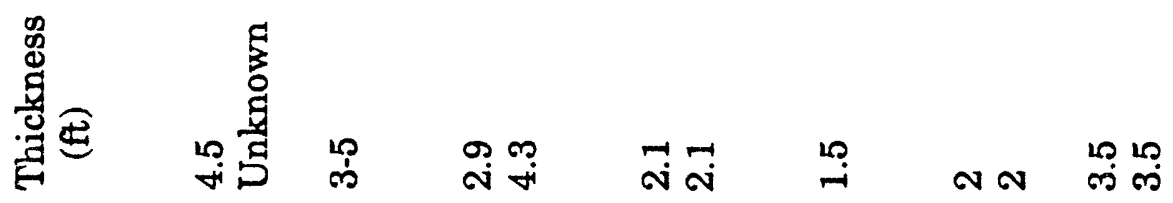

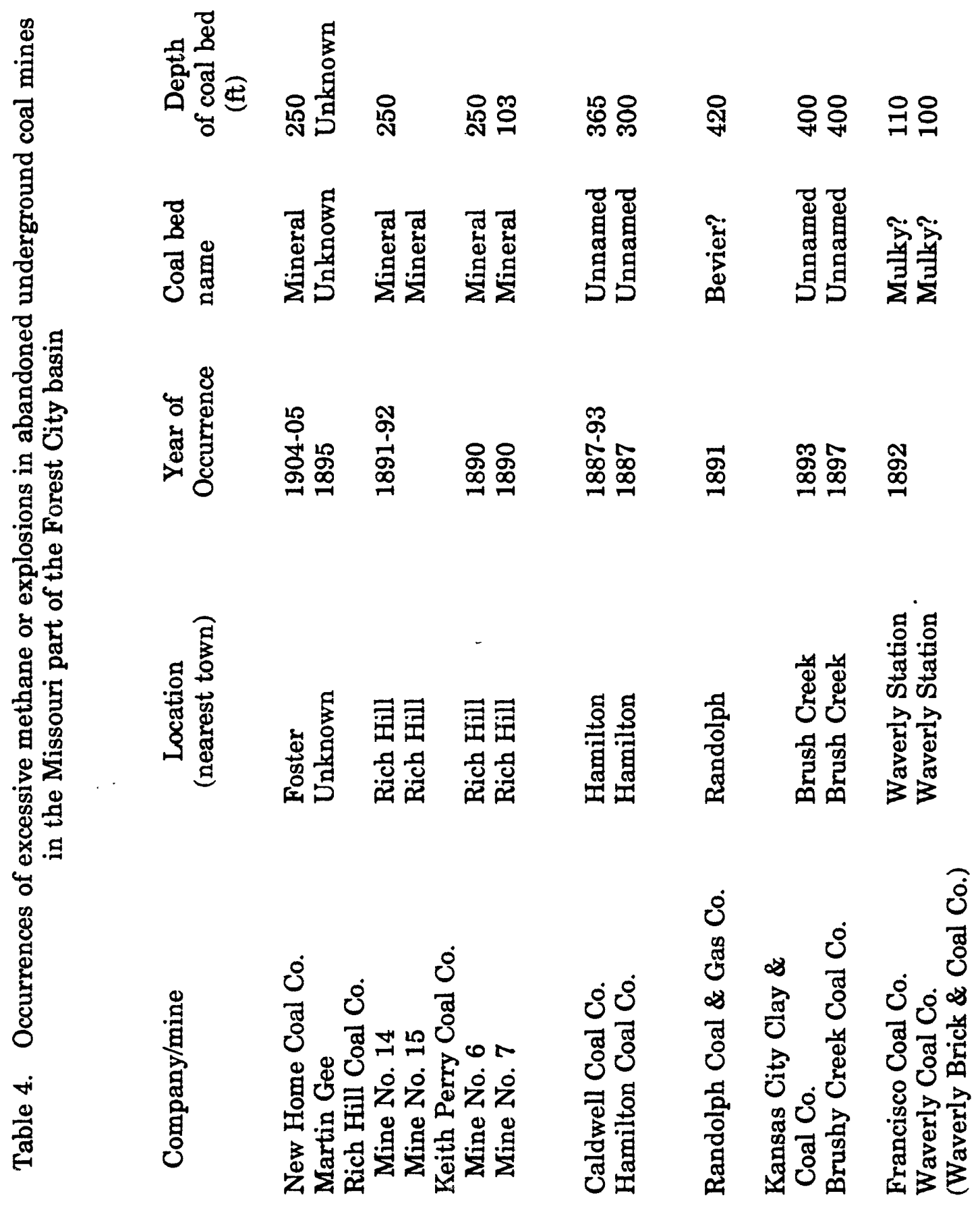

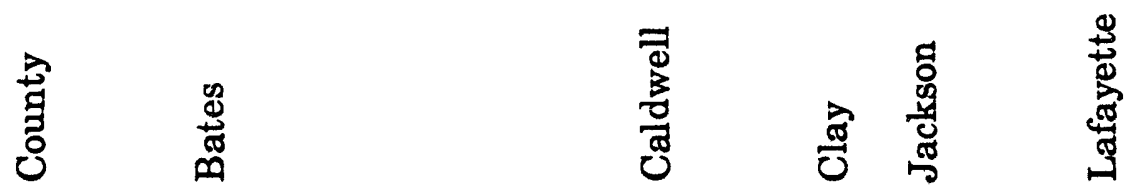




\section{APPENDIX}

\section{Economic Scenarios for Missouri}

The following economic scenarios were prepared by the Missouri Department of Natural Resources, Division of Geology and Land Survey as their analysis of the potential economic benefits from a coal-bed methane industry specifically to the State of Missouri (table 5). Because the total methane resources in the Forest City basin are unknown at present, each scenario was prepared by using a different projected number of operating wells in order to compare the economic impacts of coal-bed methane industries of different sizes. The numbers of operating wells in scenarios I through IV are 910, 500, 200 and 50. The economic benefits to Missouri in each of the four scenarios were calculated by the Missouri Department of Economic Development by utilizing a computer economic modeling program developed by the School of Business of the University of Missouri-Columbia; this program determines the total economic benefits generated by the natural gas production sector of Missouri's economy. The annual payroll from new jobs and the annual value of coalbed methane production were the initial figures put into the computer program. Raw data used to determine the value of coal-bed methane production in each economic scenario for Missouri were projected from economic data generated by Alabama's coalbed methane industry.

Scenario I: Economic benefits to Missouri under scenario I represent a best-case scenario of a coal-bed methane industry=an industry the size of that currently operating in Alabama. In 1 year, an industry producing 23.4 billion $\mathrm{ft}^{3}$ of gas from. 910 wells and employing 590 people would generate $\$ 74$ million in economic benefits to the State of Missouri from business and industry, increased personal income, and local and State government revenue.

Scenario II: Scenario II represents an industry roughly half the size of that presented in scenario I and was prepared on the basis of the value of production from 500 wells and an annual payroll from 325 new jobs. Economic benefits to the State of Missouri from an industry this size would be $\$ 40.9$ million annually.

Scenario III: Should coal-bed methane be found in producible quantities sufficient to support an industry of only 200 methane wells, annual economic benefits to Missouri would be $\$ 16.4$ million. Annual payroll would be $\$ 2.7$ million from $130 \mathrm{new}$ jobs.

Scenario IV: Scenario IV presents a very conservative estimate of the size of a coalbed methane industry in Missouri. However, it was included in this assessment to show that even a small-scale industry would generate a considerable amount of general revenue. This scenario would represent a small production area in the 
Bostic, J.L. and others, 1990, Geology of the southern part of the Southwest Coal Field, Missouri, in Finkelman, R.B., and others, eds., Coal geology of the Interior Coal Province, Western Region: annual meeting of The Geological Society of America, Coal Geology Division field trip.

Brady, L.L., 1990, Kansas coal resources, production, and potential use in the near future, in Finkelman, R.B., Friedman, S.A., and Hatch, J.R., eds., Coal geology of the interior coal province, western region: Geological Society of America Coal Geology Division field trip, p. 107-127.

Brady, L.L. and Hatch, J.R., in review, Chemical analyses of coal (Middle and Upper Pennsylvanian) from southeast Kansas: Kansas Geological Survey Mineral Resource Series.

Brady, L.L., Livingston, N.L., and Adams, D.B., 1976, Strippable coal reserves in Kansas: Kansas Geological Survey Mineral Resources Series 5, 40 p.

Brenner, R.L., 1989, Stratigraphy, petrology, and paleogeography of the upper portion of the Cherokee Group (Middle Pennsylvanian), eastern Kansas and northeastern Oklahoma: Kansas Geological Survey, Geology Series 3, 69 p.

Bunker, B.J., 1981, Phanerozoic structural development in the area of the Forest City Basin, southwestern Iowa (a brief overview): Iowa Geological Survey Annual Report Regional Tectonics and Seismicity of Southwestern Iowa, $61 \mathrm{p}$.

Bunker, B.J., Witzke, B.J., Watney, W.L., and Ludvigson, G.A., 1988, Phanerozoic history of the central midcontinent, United States, in Sloss, L.L., ed., Sedimentary Cover-North American Craton; U. S.: Boulder, Colorado, Geological Society of America, The Geology of North America, v. D-2.

Burchard, E.F., 1903, Geology of Dakota County, Nebraska, with special reference to the lignite deposits: Sioux City, Iowa, Acad. Science and Letters Proc., v. 1, p. 135-184.

Burchard, E.F., 1904, Lignites of the middle and upper Missouri Valley: U.S. Geological Survey Bulletin 225, p. 276-288.

Burchett, R.R., 1977, Coal resources of Nebraska: University of Nebraska, Conservation and Survey Division, Nebraska Geological Survey Resource Report No. 8, 185 p.

Burchett, R.R., 1979, The Mississippian and Pennsylvanian (Carboniferous) Systems in the United States--Nebraska: U. S. Geological Survey Professional Paper 1110-P, 13 p.

Burchett, R.R., 1987, Mineral resource map of Nebraska: University of Nebraska-Lincoln, Conservation and Survey Division, Nebraska Geological Survey Map. Scale 1:1,000,000.

Burchett, R.R., 1990, Coal resources of Nebraska in Coal Geology of the Western Region, Interior Coal Provinces, eds., Friedman, F.A., Finkelman, R.B., and Hatch, J.R., Geological Society of America Coal Geology Division field trip.

Burchett, R.R., 1990 (revised 1991), Coal deposits in Nebraska: University of Nebraska-Lincoln, Conservation and Survey Division, Nebraska Geological Survey, Nebraska Geonotes, 3 p. 
Burchett, R.R., Anderson, R.R., Brady, L.L., and Deason, K.L., 1983, Mineral resource map of the Forest City basin and adjacent regions of Iowa, Kansas, Missouri, and Nebraska: Nebraska Geological Survey.

Burchett, R.R., Paul, S.E., Deason, K.L., Netzler, B.L., and Anderson, R.R., 1983, Deep well and oil-gas field location map of the Forest City basin and adjacent regions of Iowa, Kansas, Missouri, and Nebraska: Nebraska Geological Survey.

Campbell, M.R. and Parker, E.W. 19n9, Coal fields of the United States: U.S. Geological Survey Bulletin 394, p. 7-26.

Chamberlain, R.E., 1980, Geology of the Forest City Basin in Iowa: Tectonic activity and influence on Pennsylvanian sedimentation: Unpub. M. S. thesis, Iowa State University, Ames, Iowa.

Clapp, A.W., 1902, Coal in Nebraska: Engineering and Mining Journal, v. 73, no. 14, 481 p.

Cline, L.M. and Greene, F.C., 1950, A stratigraphic study of the upper Marmaton and lowermost Pleasanton Groups, Pennsylvanian, of Missouri: Missouri Division of Geological Survey and Water Resources, Report of Investigations No. 12.

Close, J.C. and Erwin, T.M., 1989, Significance and determination of gas content data as related to coalbed methane reservoir evaluation and production implications, in Proceedings of the 1989 Coalbed Methane Symposium at University of Alabama/Tuscaloosa, p. 37-55.

Coalbed Methane Association of Alabama, 1990, Coalbed methane: Alabama's energy opportunity, Tuscaloosa News, Sunday, Oct. 7, Tuscaloosa, AL.

Condra, G.E., 1907, Geology and water resources of the Republican River valley and adjacent areas: U.S. Geological Survey Water-Supply Paper 216, 71 p.

Condra, G.E., 1908, Geology and water resources of a portion of the Missouri River valley in northeastern Nebraska: U.S. Geological Water-Supply Paper 215, 59 p.

Condra, G.E., 1922, Coal in Nebraska: Nebraska Blue Book, p. 359-62.

Condra, G.E., 1923, Nebraska resources and industries: University of Nebraska-Lincoln, Conservation and Survey Division Bulletin 16, p. 34 .

Condra, G.E., 1924, Coal and bituminous shale in Nebraska: Nebraska Blue Book, p. 341-44.

Condra, G.E., 1927, The stratigraphy of the Pennsylvanian System in Nebraska: Nebraska Geological Survey Bulletin 1, 2nd Ser., 291 p.

Condra, G.E. and Reed, E.C., 1959, The geological section of Nebraska: University of Nebraska-Lincoln, Conservation and Survey Division, Nebraska Geological Survey Bulletin $14 \mathrm{~A}$, p. $20,49,54-58$.

Deason, K.L. and Bohm R., 1988, Studies of the oil and gas fields of Caldwell, Clay, Clinton and Ray Counties, Missouri: Missouri Department of Natural Resources, Division of Geology and Land Survey, OFR-88-69-OG, 43 p. 
DeGraw, H.M., 1969, Subsurface relations of the Cretaceous and Tertiary in western Nebraska: University of Nebraska M.S. thesis, 137 p.

Derynck, N.P., 1980, Distribution of Des Moines Series coals in Iowa: Unpub. M. S. thesis, Iowa State University, Ames, Iowa.

Diamond, W.P. and Levine, J.R., 1981, Direct method determination of the gas content of coal: procedures and results: U.S. Bureau of Mines Report of Investigations 8515, 36 p.

Dobbs, H.J., 1918, History of Gage County, Nebraska: Western Publishing and Engraving Co., Lincoln, Nebraska, 1100 p.

Dubois, M.K, 1985, Leavenworth field in Kansas oil and gas fields (v. 5): Kansas Geological Society, Wichita, Kansas, p. 149-158.

Ebanks, W.J., Jr., 1979, Correlation of Cherokee (Desmoinesian) sandstones of the Missouri-Kansas-Oklahoma tri-state area, in Hyne, N.J., ed., Pennsylvanian Sandstones of the Mid-Continent: Tulsa Geological Society, Inc., Tulsa, Oklahoma, p. 295-312.

Ebanks, W.L., Jr., James, G.W., and Livingston, N.D., 1977, Evaluation of heavy-oil and tar sands in Bourbon, Crawford, and Cherokee counties, Kansas-- Final Report: United States Department of Energy, Bartlesville Energy Research Center Report of Investigations 77/20, $110 \mathrm{p}$.

Edwards, L.S., 1917, History of Richardson County, Nebraska: B.F. Bowen \& Co., Inc., Indianapolis, Indiana, $1417 \mathrm{p}$.

Finkelman, R.B. and Tewalt, S.J., 1990, Summary of analytical data for coals from the Western Region of the Interior Coal Provinces in Coal Geology of the Western Region, Interior Coal Provinces, eds. Friedman, S.A., Finkelman, R.B., and Hatch, J.R: Geological Society of . America Coal Geology Division field trip, p. 200-228.

Furnas, R.W., 1859, Business directory of Brownville and Nemaha County, Nebraska, with a historical sketch: R.W. Furnas Book \& Job Printer, Brownville, Nebraska.

Furnas, R.W., 1870, Nebraska--a sketch of its history, resources, and advantages it offers to settlers: Nebraska State Board of Immigration pamph., Nebraska City, Nebraska.

Garvin, P.L., Sammis, N., Berchenbriter, D., and Van Eck, O.J, 1975, Strippable coal reserve study in selected Iowa counties: Iowa Geological Survey Misc. Pub. 10, 19 p.

Garvin, P.L. and Van Eck, O.J, 1976, Strippable coal reserve study in seven Iowa counties: Iowa Geological Survey Misc. Pub. 11, 27 p.

Gentile, R.J., 1976, The geology of Bates County, Missouri: Missouri Department of Natural Resources, Division of Geology and Land Survey, Report of Investigation No. 59.

Gentile, R.J., 1984, Geology of the Belton quadrangle: Missouri Department of Natural Resources, Division of Geology and Land Survey, Report of Investigations No. 69, 110 p.

Harris, J.W., 1984, Stratigraphy and depositional environments of the Krebs Formation (Lower 
Cherokee Group, Middle Pennsylvanian) in southeastern Kansas: Unpub. M. S. thesis, University of Kansas, $139 \mathrm{p}$.

Harris, J.W., Brady, L.L., and Walton, A.W., 1985, Stratigraphy and depositional environments--Krebs Formation in southeastern Kansas (Abs.): American Association of Petroleum Geologists, v. 69 , p. 1317-1318.

Harvey, A.F., 1869, Nebraska as it is--a description of the soil, climate, productions, mineral, and agricultural resources of the state of Nebraska: Statesman Printing Office, Lincoln, Nebraska, 37 p. (Also published under title "The State of Nebraska" in Nebraska State Board of Agriculture Report 1869, p. 56-68.)

Hatch, J.R., Avcin, M.J., and VanDorpe, P.E., 1984, Element geochemistry of Cherokee Group coals (Middle Pennsylvanian) from south-central and southeastern Iowa: Iowa Geological Survey Technical Paper 5, 108.p.

Haworth, E. and Crane, W.R., 1898, Special Report on Coals: Kansas University Geological Survey, v. 3, p. 1-347.

Hayden, F.V., 1867, First annual report of the United States Geological Survey of the territories embracing Nebraska: U.S. General Land Office Report 1867, p. 100-107.

Hayden, F.V., 1868, Remarks on the possibility of a workable bed of coal in Nebraska: American Journal of Science and Arts, 2nd Ser., v. 45, p. 326-330.

Hayden, F.V., 1869, Lignite beds of the upper Missouri: American Philosophical Soc. Proc., v. 10, p. 274-275.

Hayden, F.V., 1872, Final report of the United States Geological Survey of Nebraska and portions of the adjacent territories: U. S. 42d Congress, 1st sess., House Ex. Doc. 19, 264 p.

Heckel, P.H., 1977, Origin of phosphatic black shale facies in Pennsylvanian cyclothems of midcontinent North America: American Association of Petroleum Geologists, v. 61, p. 1045-1068.

Hershey, H.G., 1969, Geological map of Iowa showing the indurated rocks exposed or immediately beneath the glacial deposits: Iowa Geological Survey, Map Ser. 9.

Hershey, H.G., Brown, C.N., Van Eck, O.J, and Northup, R.C., 1960, Highway construction materials from the consolidated rocks of southwestern Iowa: Iowa Geological Survey and Iowa Highway Research Board Bulletin 15, $151 \mathrm{p}$.

Hicks, L.E., 1888, Nebraska in Ashburner, C.A., Coal: U.S. Geological Survey Mineral Resources of the United States, calendar year 1887, p. 168-382.

Hinds, H., 1909, Coal deposits of Iowa: Iowa Geological Survey Annual Report, v. 19, p. 21-396.

Hinds, H. and Greene, F.C., 1915, The stratigraphy of the Pennsylvanian Series in Missouri: Missouri Bureau of Geology and Mines, v. 13, 2nd Ser.

Hinds, H. and Greene, F.C., 1917, Leavenworth-Smithville folio, Missouri-Kansas: U. S. Geological 
Survey Folio no. 206, 13 p.

Howe, W.B., 1953, Upper Marmaton strata in western and northern Missouri: Missouri Division of Geological Survey and Water Resources, Report of Investigations no. 9.

Howe, W.B., 1956, Stratigraphy of pre-Marmaton Desmoinesian (Cherokee) rocks in southeastern Kansas: Kansas Geological Survey Bulletin 123, 132 p.

Howe, W.B. and Searight, W.V., 1953, Coal in northeastern Carroll County and southeastern Livingston County, Missouri: Missouri Division of Geological Survey and Water Resources, Report of Investigations No. 14.

Howes, M.R., 1988, Evaluation of coal resources in Wapello and Davis counties, Iowa using computerized databases for resource estimates and mapping: Unpub. contract report, Iowa Department of Natural Resources, $71 \mathrm{p}$.

Howes, M.R., 1990, Development of a coal resource database in the Iowa Natural Resources Geographic Information System for Monroe County, Iowa: Iowa Department of Natural Resources Open-File Report 90-2, 70 p.

Huffman, D.P., 1991, Stratigraphy and depositional environments of the Cherokee Group (Middle Pennsylvanian), Bourbon arch region, East-Central Kansas: Unpub. M. S. thesis, University of Kansas, 204 p.

Huse, W.N., 1896, The history of Dixon County, Nebraska: Press of the Daily News, Norfolk, Nebraska, 372 p.

Iowa Department of Natural Resources, Natural Resources Geographic Informations Sysiem, Coal mine, coal resource, and geologic sampling points databases.

Iowa Department of Natural Resources-Geological Survey Bureau open files, Riverton Core.

Jewett, J.M., 1951, Geologic structures in Kansas: Kansas Geological Survey Bulletin 90, Pt. 6, 172 p.

Jewett, J.M., O’Connor, H.G., and Zeller, D.E., 1968, Pennsylvanian system, in Zeller, D.E., ed., The stratigraphic succession in Kansas: Kansas Geological Survey Bulletin 189, p. 21-43.

Kaplan, S.S., 1980, The sedimentology, coal petrology and trace element geochemistry of coal-bearing sequences from Joggins, Nova Scotia, Canada, and southeastern Nebraska, USA: Unpub. Ph.D. dissertation, University of Pittsburgh.

Keyes, C.R., 1894, Coal deposits of Iowa: Iowa Geological Survey Annual Report, v. 2, 536 p.

Lee, W., 1941, Preliminary report on the McLouth gas and oil field, Jefferson and Leavenworth counties, Kansas: Kansas State Geological Survey Bulletin 38, pt. 10, p. 261-284.

Lee, W., 1943, The stratigraphy and structural development of the Forest City basin in Kansas: Kansas Geological Survey Bulletin 51, 142 p.

Lee, W., Grohskopf, J.G., Greene, F.C., Hershey, H.G., Harris, S.E., Jr., and Reed, E.C., 1946, 
Structural development of the Forest City Basin of Missouri, Kansas, Iowa and Nebraska: U.S. Geological Survey Oil and Gas Inv. Prelim. Map 48.

Lee, W. and Merriam, D.F., 1954, Cross sections in eastern Kansas: Kansas Geological Survey Oil and Gas Investigations no. 12, 8 p.

Lee, W. and Payne, T.G., 1944, McLouth gas and oil field, Jefferson and Leavenworth counties, Kansas: Kansas Geological Survey Bulletin 53, 195 p.

Lees, J.H., 1927, Iowa coal areas and characteristics of Iowa coal, in Kay, G.F., 1926, Annual Reports, 1925 and 1926: Iowa Geological Survey Annual Report, v. 32, p. 65-81.

Lemish, J., Burggraf, D.R., Jr., and White, H.J., eds., 1981, Cherokee Sandstones and related facies of central Iowa: An examination of tectonic setting and depositional environments: Iowa Geological Survey Guidebook Series no. 5, 95 p.

Lemish, J. and Palmquist, R.C., 1980, Final report: the geology of the deep coal in Iowa: U. S. Department of Energy Report Contract No. DE AC21-77ET12523, p. 1-104.

Livingston, N.D. and Brady, L.L., 1981, Preliminary coal resource evaluation of the Cherokee Group (Middle Pennsylvanian) within the Forest City Basin of northeast Kansas (Abs.): Geological Society of America Abstracts with Programs, v. 13, no. 6, p. 286.

Manley, R.N., 1966, Wealth beneath the prairie--the search for coal in Nebraska: Nebraska State Historical Society, Nebraska History, Lincoln, Nebraska, v. 47, no. 2, p. 157-176.

McCourt, W. E., 1917, The geology of Jackson County, Missouri: Missouri Bureau of Geology and Mines, v. 14, 2nd Ser.

McCracken, M.H., 1971, Structural features of Missouri: Missouri Geological Survey and Water Resources, Report of Investigations no. 49, 99 p.

McCulloch, C.M., Levine, J.R., Kissell, F.N., and Deal, M., 1975, Measuring the methane content of bituminous coal beds: U.S. Bureau of Mines, Report of Investigations $\mathrm{Ne} 8043,22 \mathrm{p}$.

McQueen, H.S. and Greene, F.C., 1938, The geology of northwestern Missouri: Missouri Geological Survey and Water Resources, v. 25.

Merriam, D.F., 1960, Preliminary regional structural contour map on top of Mississippian rocks in Kansas: Kansas Geological Survey, Oil and Gas Investigations No. 22, Map.

Miller, G.L., 1907, Early dreams of coal in Nebraska: Nebraska State Historical Society Proc. and Collections, Lincoln, Nebraska, v. 15, p. 189-192.

Missouri Bureau of Mines, Mining and Mine Inspection, 1887-1905, annual reports: State of Missouri.

Nelson, M.R., 1985, Petrology, diagenesis, and depositional environment of the Lagonda interval, Cabaniss Subgroup, Cherokee Group, Middle Pennsylvanian, in northeastern Kansas: Unpub. M. S. thesis, University of Iowa. 
Netzler, B.W., 1982, Map of total dissolved solids concentrations in groundwater from the Lower Pennsylvanian (Atokan Series and Cherokee Group) in Missouri: Missouri Department of Natura! Resources, Division of Geology and Land Survey, Open-File Map Series OFM-82-60-WR, 1:1,000,000.

Netzler, B.W., 1982, Map of total dissolved solids concentrations in groundwater from the Middle Pennsylvanian (Pleasanton and Marmaton Groups) in Missouri: Missouri Department of Natural Resources, Division of Geology and Land Survey, Open-file Map Series OFM-82-59-WR, 1:1,000,000.

Newell, K.D., Watney, W.L., Cheng, S.W.L., and Brownrigg, R.L., 1987, Stratigraphic and spatial distribution of oil and gas in Kansas: Kansas Geological Survey, Subsurface Geology Series 9,86 p.

Nuelle, L.M., 1990, Stratigraphic seting of Late Atokan and Early Desmoinesian (Pennsylvanian) coals of the Missouri portion of the Joplin $1^{\circ} \times 2^{\circ}$ quadrangle, southwest Missouri in Finkelman, R.B., and others, eds., Coal geology of the Interior Coal Province, Western Region: annual meeting of The Geological Society of America, Coal Geology Division field trip.

Olin, H.L., 1965, Iowa coal studies: Iowa Geological Survey Technical Paper 3, 80 p.

Pabian, R.K, 1971, Minerals and gemstones of Nebraska: University of Nebraska-Lincoln, Conservation and Survey Division, Educational Circular no. 2, p. 27.

Palmer, J.R., 1981, Isopachous map of the Pennsylvanian System in Missouri: Missouri Department of Natural Resources, Division of Geology and Land Survey, OFM-81-38 GI, scale 1:000,000.

Parker, E.W., 1892, Coal: U. S. Geological Survey Mineral Resources of the United States, calendar years 1889 and 1890 , p. 145-286.

Parker, E.W., 1893, Coal: U.S. Geological Survey Mineral Resources of the United States, calendar year 1891, p. 177-356.

Parker, E.W., 1901, Coal: U.S. Geological Survey Mineral Resources of the United States, calendar year 1900 , p. 273-457.

Parker, E.W., 1902, Coal: U.S. Geological Survey Mineral Resources of the United States, calendar year 1901, p. 279-449.

Parker, E.W., 1908, Coal: U.S. Geological Survey Mineral Resources of the United States, calendar year 1907, part 2, Nonmetallic products, p. 5-222.

Pepperburg, R.V., 1910, Coal in Nebraska: Nebraska Geological Survey, v. 3, part 10, p. 275-307.

Peppers, R.A. and others, 1993, Palynological Zonation and physical stratigraphy of Pre-Desmoinesian strata along a subsurface cross section in northwestern Missouri: The Geological Society of America, North-Central Section Meeting, Rolla, Missouri (Abs.). 
Rascoe, B.A. and Adler, F.J., 1983, Permo-Carboniferous hydrocarbon accumulations, -midcontinent U.S.A.: American Association of Petroleum Geologists Bulletin, v. 67, no. 6, p. 979-1001.

Ravn, R.L., 1986, Palynostratigraphy of the lower and middle Pennsylvanian coal of Iowa: Iowa Geological Survey Technical Paper No. 7, 245 p.

Ravn, R.L., Swade, J.W., Howes, M.R., Gregory, J.L., Anderson, R.R., and VanDorpe, P.E., 1984, Stratigraphy of the Cherokee Group and revision of Pennsylvanian stratigraphic nomenclature in Iowa: Iowa Geological Survey Tech. Inf. Ser. 12, 76 p.

Rightmire, C.T., 1984, Coalbed methane resource in Rightmire, C.T., et al., Coalbed methane resources of the United States: AAPG Studies in Geology Series no. 17, p. 1-13.

Robertson, C.E., 1971, Evaluation of Missouri's coal resources: Missouri Geological Survey and Water Resources, Report of Investigations No. 48.

Robertson, C.E., 1974, Mineable coal reserves of Missouri: Missouri Geological Survey and Water Resources, Report of Investigations No. 54.

Robertson, C.E., 1979, Coal availability in Missouri: Missouri Department of Natural Resources, Division of Geology and Land Survey, OFR-79-4-ER.

Robertson, C.E. and Smith, D.C., 1981, Coal resources and reserves of Missouri: Missouri Department of Natural Resources, Division of Geology and Land Survey, Report of Investigations 66 .

Rosowitz, D.W., 1980, Palynology and paleoecology of the Riverton coal bed (Desmoinesian, Pennsylvanian) in southeastern Kansas: Unpub. M. S. thesis, Wichita State University, 137 p.

Schrader, F.C., Stone, R.W., and Sanford, Samuel, (compilers), 1917, Useful minerals of the United States: U. S. Geological Survey Bulletin 624, 412 p.

Searight, W.V. and Howe, W.B., 1961, Pennsylvanian system, in Howe, W.B. and Koenig, J.W., eds., The stratigraphic succession in Missouri: Missouri Geological Survey and Water Resources, Report of Investigations 40, Ser. 2, p. 78-122.

Searight, W.V., Howe, W.B., Moore, R.C., Jewett, J.M., Condra, G.E., Oakes, M.C., and Branson, C. C., 1953, Classification of Desmoinesian (Pennsylvanian) of northern midcontinent: American Association of Petroleum Geologists Bulletin, v. 37, p. 2747-2749.

Staton, M.D., 1987, Stratigraphy and depositional environments of the Cherokee Group (Middle Pennsylvanian) central Cherokee Basin, southeastern Kansas: Unpub. M. S. thesis, University of Kansas, 102 p.

Staton, M.D., Brady, L.L., and Walton, A.W., 1987, Stratigraphy and depositional environment of the Cherokee Group (Desmoinesian, Middle Pennsylvanian), central Cherokee basin, southeast Kansas (Abs.): American Association of Petroleum Geologists, v. 71, p. 998.

Steeples, D.W., 1988, Structure of the Salina-Forest City interbasin boundary from seismic studies, 
in Steeples, D.W., ed., Geophysics in Kansas: Kansas Geological Survey Bulletin 226, p. 31-52.

Stoeckinger, W.T., 1989, Methane from coal in southeast Kansas: The rebirth of an old industry: in Proceedings of the 1989 Coalbed Methane Symposium at University of

Alabame:Tuscaloosa, p. 211-217.

Strickland, M.O., 1987, The areal distribution and depositional setting of the McLouth Sandstone in Jefferson and Leavenworth counties, Kansas: Unpub. M. S. thesis, University of Southwestern Louisiana.

Swade, J.W., ed. Heckel, P.H., 1985, Conodont distribution, paleoecology, and preliminary biostratigraphy of the upper Cherokee and Marmaton groups (Upper Desmoinesian, Middle Pennsylvanian) from two cores in south-central Iowa: Iowa Geological Survey Tech. Inf. Ser. 14,71 p.

Swanson, V.E., Medlin, J.H., Hatch, J.R., Coleman, S.L., Wood, G.H., Jr., Woodruff, S.D., and Hildebrand, R.T., 1976, Collection, chemical analysis, and evaluation of coal samples in 1975: U.S. Geological Survey Open-File Report 76-468, 503 p.

Taylor, S.R., 1964, Abundance of chemical elements in the continental crust--a new table: Geochemica et Cosmochimica Acta, v. 28, no. 8, p. 1273-1285.

Tedesco, S.A., 1992, Coalbed methane potential assessed in Forest City Basin: Oil and Gas Journal, Feb. 10, 1992, p. 68-72.

Tewalt, S.J. and Finkelman, R.B., 1990, Analytical data from bituminous coals and associated rocks from Arkansas, Iowa, Kansas, Missouri, Nebraska and Oklahoma: U.S. Geological Survey Open-File Report.

Thompson, T.L., 1979, The Mississippian and Pennsylvanian (Carboniferous) systems in the United States-Missouri: Geological Survey Professional Paper 1110-N, p. 1-22.

Turekian, K.K. and Wedepohl, K.H., 1961, Distribution of the elements in some major units of the earth's crust: Geological Society of America Bulletin, vv. 72, no. 2, p. 175-191.

Van Eck, O.J. and Landis, E.R., 1965, Coal Resources of Iowa: Iowa Geological Survey, Tech. Paper 4, $141 \mathrm{p}$.

Wanless, H.R., 1975, Distribution of Pennsylvanian coal in the United States, in McKee, E.D. and Crosby, E.J., eds., Paleotectonic investigations of the Pennsylvanian system of the United States, Part 2. Interpretive summary and special features of the Pennsylvanian system: Geological Survey Professional Paper 853, p. 33-56.

Visuless, H.R., Baroffio, J.R., and Trescott, P.C., 1969, Conditions of deposition of Pennsylvanian coal beds, in Dapples, E.C. and Hopkins, M.E., eds., Environments of coal deposition: Geological Society of America Special Paper No. 114, p. 105-142.

Wedge, W. and Hatch, J.R., 1980, Chemical composition of Missouri coals: Missouri Department of Natural Resources, Division of Geology and Land Survey, Report of Investigation Number $63,102 \mathrm{p}$. 
Wells, J.S., 1971, Forest City basin in Cram, I.H. (ed.), Future petroleum provinces of the United States--their geology and potential: American Association of Petroleum Geologists, Memoir 15 (v. 2), p. 1098-1103.

Wells, J.S., 1979, Inventory of heavy-oil in western Missouri, Final Report: United States Department of Energy, Bartlesville Energy Technology Center 1808-1, 191 p.

White, C.A., 1868, On coal in Nebraska: American Journal of Science, 2nd Ser., No. 45, p. 399-400.

Wilson, L.R., 1979, Palynological evidence for age assignment of basal Cherokee (Pennsylvanian) strata in southeastern Kansas: Abstract from Oklahoma Geology Notes, v. 39, p. 76-79.

Winslow, A., 1891, A preliminary report on the coal deposits of Missouri: Geological Survey of Missouri.

Wojcik, K.M., 1991, Diagenesis of Pennsylvanian sandstones and limestones, Cherokee basin, southeastern Kansas: Importance to fluid flow: Unpub. Ph.D. dissertation, University of Kansas, 349 p.

Wood, G.H., Jr., Kehn, T.M., Carter, M.D., and Culbertson, W.C., 1983, Coal resource classification system of the U.S. Geological Survey: U.S. Geological Survey Circ. 891, 65 p.

Young, C.M. and Allen, H.C., 1925, Kansas coal: Kansas University Bulletin 13, 202 p.

Zeller, D.E., ed., 1968, The stratigraphic succession in Kansas: Kansas Geological Survey Bulletin $189,81 \mathrm{p}$. 